\title{
Does Judicial Efficiency Lower the Cost of Credit?
}

\author{
Luc Laeven and Giovanni Majnoni*
}

\begin{abstract}
We investigate the effect of judicial efficiency on banks' lending spreads for a large cross section of countries. We measure bank interest rate spreads for 106 countries at an aggregate level and for 32 countries at the level of individual banks. We find that, after controlling for a number of other country characteristics, judicial efficiency, in addition to inflation, is the main driver of interest rate spreads across countries. This suggests that in addition to improving the overall macroeconomic climate in a country, judicial reforms, through a better enforcement of legal contracts, are critical to lowering the cost of financial intermediation for households and firms.
\end{abstract}

JEL Classification: D23,G21,G32,K42

Keywords: Interest Rate Spreads, Financial Intermediation, Law and Finance

World Bank Policy Research Working Paper 3159, October 2003

The Policy Research Working Paper Series disseminates the findings of work in progress to encourage the exchange of ideas about development issues. An objective of the series is to get the findings out quickly, even if the presentations are less than fully polished. The papers carry the names of the authors and should be cited accordingly. The findings, interpretations, and conclusions expressed in this paper are entirely those of the authors. They do not necessarily represent the view of the World Bank, its Executive Directors, or the countries they represent. Policy Research Working Papers are available online at http:/lecon.worldbank.org.

* The authors are from the World Bank. Email: 1laeven@worldbank.org and gmajnoni@worldbank.org. We are grateful to Guillermo Noguera for excellent research assistance. 


\section{Introduction}

One of the motivations behind judicial reforms is that they improve the investment climate. It is believed that a transparent and efficient judiciary system by providing a better protection of creditor rights and faster trials in the occurrence of a loan default may reduce the uncertainty surrounding the outcome of loans payoffs in a bad state of the world. A larger amount of recovery and a shorter time to repossess collateral in the event of default are thought to induce banks to reduce the spread over borrowing rates and charge their customers a lower lending rate. By reducing the level of real lending rates banks succeed not only in reaching out customers further down in the demand curve but also, by reducing the relevance of adverse selection and moral hazard phenomena, they are likely to succeed in widening the supply of credit to previously rationed customers.

While there is a rather uncontroversial evidence that a more efficient judicial system and a more effective protection of creditor rights succeed in improving the access of the corporate sector to external finance we lack a parallel conclusive evidence on the effects of judicial reforms on the cost of finance. La Porta et al. (1997), Demirguc-Kunt and Maksimovic (1998), and Galindo (2001) have shown for a cross section of countries that better creditor rights protection improves the access to external finance, while a series of works by Bianco, Jappelli, and Pagano (2001), Castelar, Pineiro, and Cabral (2001), and Cristini, Moya, and Powell (2001) have shown that different levels of judicial protection of creditor rights is associated with different volumes of bank lending even within individual countries. Compared with these results we have only indirect evidence of the impact of the same variables on the cost of capital and on the cost credit. Claessens 
et al. (2002) find that market valuation of listed firms is higher with a better protection of creditor rights, pointing to a lower cost of capital and a lower discount rate of future earnings. On the cost of credit side, international and national evidence is blurred.

The reasons of the asymmetry in available empirical evidence are twofold: theoretical and empirical. On the theoretical front the impact of a more efficient organization and enforcement of justice on interest rates is not unambiguous due to the simultaneous presence of two countervailing effects. On one side there is the unambiguous positive effect of an increased recovery in the event of default on (reducing) the lending spread. On the other hand there is the negative impact related to a composition effect by which riskier and previously rationed bank customers may, as a result of more efficient judicial procedures, access bank credit. This new cohort of customers will in fact carry higher rates that may offset the lower rates possibly charged to old borrowers. In addition, there is the possibility that banks enjoying a dominant position on their respective market may take the opportunity of a more efficient judicial system to extract higher rents from their borrowers (Bianco, Jappelli, and Pagano, 2001).

On the empirical side, the theoretical indeterminacy is reflected in contrasting evidence at the national level. For instance, Bianco et al. (2001) do not find significant effects on bank spreads in the Italian loan market while Meador (1982) finds significant effects on the U.S. mortgage market. We lack similar evidence at the international level, as the substantial absence of good quality data on lending spreads has proved to be a major impediment to empirical analysis. We have therefore only the indirect evidence provided by the positive association of judicial reforms with the ratio of banks' net interest income (NII) over total assets, used by Demirguc-Kunt and Huizinga (1998) as a 
proxy for bank efficiency. Unfortunately the latter association is not sufficient to infer the effects of judicial efficiency on the cost of credit as the ratio may be affected by several assets composition effects. For example, a decrease of NII may derive from an increase of fixed assets or government bonds at the expenses of the loan portfolio. Another potentially important source of bias is given by the inclusion among total assets of noninterest accruing non-performing loans (NPLs). Other analysis of the determinants of bank interest rate margins such as Ho and Saunders (1981) and Saunders and Schumacher (2000) have tried to control for these factors through a two-stage regression procedure, but none of these studies focuses explicitly on the effects of judicial efficiency.

In this paper we shall focus explicitly on the cost of bank credit, but we believe that our results could be taken as indicative of the wider impact of judicial inefficiency on the cost of external finance. The policy relevance of an empirical evaluation of the relationship between the cost of credit and judicial reforms is manifold.

The quantification of the average impact that better judicial protection of property rights has on the level of lending rate may help to visualize the gains that a cooperative behavior may bring to the often opposed constituencies of bank debtors and of bank creditors. The potential reduction of the cost of credit would in fact show the extent to which a better protection of the creditors could help the debtors to access cheaper sources of finance.

It may also show which one of the competing forces that in principle affect lending rates is stronger and matters from the standpoint of countries at a different level of development. For instance, the cross country evidence provided by Demirguc-Kunt 
and Huizinga (1998) points to large benefits of judicial efficiency on the reduction of banks' net interest income, independently from any notion of market power. This may hide different levels of judicial effectiveness across developed and developing countries where typically banking markets are more concentrated and judges could more likely be captive of the economic power. Additional empirical evidence may therefore signal to what extent judicial reform and competition policies should go hand in hand in order to effectively bring forward an effective reduction of the cost of credit in emerging economies. From this perspective our paper is closely related to the paper by DemirgucKunt, Laeven, and Levine (2003), that uses net interest margins as a measure of the bank inefficiency and shows that countries with better institutions (including better property rights) have lower margins and to the paper by Claessens, Demirguc-Kunt, and Huizinga (2001) that investigates the role of foreign banks in a cross-country study and shows that foreign bank entry reduces net interest margins.

The paper proceeds as follows. Section 2 presents the criteria followed in the construction of different measures of lending spreads, describes the explanatory variables and provides some descriptive statistics. Section 3 presents the estimation methodology and illustrates the main empirical results. Section 4 concludes.

\section{Methodology and Data}

\subsection{Description of bank lending spread variables.}

Our empirical analysis is based on a cross section of bank lending spreads and assesses the sensitivity of such spreads to the quality of the legal system and to a number of other country-specific variables. The dependent variable is represented by the difference 
between the average lending rate and the average cost of funds, either measured directly at the country level or measured at the level of individual banks but aggregated at the country level. The regression format is the traditional one with controlling variables at the country level and a set of institutional variables intended to capture the effects of judicial reforms.

Focusing on interest rate spreads has several advantages over comparing net interest margins, a variable typically used in cross-country work on bank efficiency. First, net interest margins are typically expressed in terms of total assets, while a correct construction of average spreads should refer interest incomes and payments separately both to the assets and the liabilities sides of the balance sheet. Second, net interest margins typically do not control for the presence of non interest earning assets such as non-performing loans. Third, net interest margins are typically based on total interest income, which also includes interest from non-lending operations, therefore limiting comparability across banks.

We construct country-level interest rate spreads following two distinct approaches in order to address possible concerns about measurement errors and the robustness of our empirical results. First, we use country-level data on average lending rates and deposit rates from the IMF's International Financial Statistics (IFS) database. The lending rate in IFS (line 60p) is defined as the bank rate that usually meets the short- and medium-term financing needs of the private sector, and the deposit rate (line 601) is defined as the average of the rates offered to resident customers for demand, time, and savings deposits. We compute the interest rate spread as the difference between the average lending rate (line 60p) and the average deposit rate (line 601) for the year 2000. For Austria and 
Portugal, we do not have data for the year 2000, and we therefore use data from 1999.

For the United Kingdom we use data from 1998. In what follows, we refer to this interest rate spread as SPREAD1. While the advantage of this proxy for lending spreads is given by the wide scope of coverage, the problem is that a number of countries do not collect comparable average rates on either deposits and/or loans. For countries with a large component of dollarized assets or liabilities it is difficult to verify whether the reported rates are referred to domestic currencies or to the average of domestic and dollar rates. Also, the reference group for which IFS reports interest rates differs across countries. For some countries, the lending rate reflects the average rate for prime borrowers in the country, while for other countries it reflects the average rate for a borrower of average quality.

Our second proxy is given by average interest rate spreads computed at a banklevel using data from Bankscope and successively aggregated at a country level. Bankscope reports balance sheet and income statement data for a large number of banks and countries. The advantage of using bank-level data is that it allows for comparison of interest rates charged by similar types of banks in different countries, while the IFS data merely reflects the spread for the average bank in the country. Using Bankscope data, we will be able to compute analytically the value of the average rate charged by an homogeneous sector of the banking system, therefore enhancing the comparability across countries. The challenge when using bank-level data on balance sheets and income statements, such as the one provided by Bankscope, is that interest rates have to be imputed from information on interest income, as data on bank-level interest rates are not reported. The problem is that in many countries, banks are not obliged to report interest 
income on loans separately, and they merely report total interest income, including interest from interbank operations and interest-earning securities, such as government and corporate bonds. Using total interest income, although more widely available, is not a realistic indicator of the return on the lending operations of each bank, and would create an upward bias of the estimated lending rate if referred to total loans. In addition, we need data on non-performing loans for each bank, since we are interested in the interest rates charged by the bank, not the interest rates earned by the bank.

To enhance comparability across countries, we compute bank-level interest rate spreads for the ten largest banks in each country, if available, and construct country-level interest rate spreads by averaging across these ten banks by country. Again, we calculate the spreads for the year 2000, the most recent year for which data are available.

In order to construct variables that measure the return on interest-earning assets and the cost of funding of those operations, we need data on interest income on the loan portfolio, interest expense, total loans, problem loans, total deposits, money market funds, and other funds. Since Bankscope does not have such an extensive coverage for the interest income on the loan portfolio or for the amount of problem loans, we had to restrict our sample to the 35 countries that offer this level of information. After selecting the ten largest banks in each country we also collected the data on problem loans and interest income on the loan portfolio from the banks' annual reports in order to crosscheck the data reported by Bankscope and insure their reliability. For a few cases (12 banks in seven countries to be exact), we found a discrepancy between the data reported by Bankscope and the data contained in the audited financial statements. For these banks, we have replaced the Bankscope data derived from the audited annual reports. 
To enhance comparability across countries, we make two further adjustments to the spread of each bank. First, we use consumer price index data to adjust for the impact of inflation on spreads. Second, as we are dividing a flow variable by a stock variable, we calculate the average of the stock variable between $t$ and $t-1$. In sum, we calculate banklevel lending rate $i_{t}^{L}$ and the bank-level deposit rate $i_{t}^{D}$ for period $\mathrm{t}$ as follows:

$$
\begin{gathered}
i_{t}^{L}=\frac{\frac{I I_{t}}{P_{t}^{a}}}{\frac{1}{2}\left(\frac{L_{t-1}}{P_{t-1}^{e}}+\frac{L_{t}}{P_{t}^{e}}\right)} \\
i_{t}^{D}=\frac{\frac{I E_{t}}{P_{t}^{a}}}{\frac{1}{2}\left(\frac{D_{t-1}}{P_{t-1}^{e}}+\frac{D_{t}}{P_{t}^{e}}\right)}
\end{gathered}
$$

where $I I$ is the interest income from the loan portfolio, $I E$ is the interest expense, $L$ represents the total performing loans (being the difference between total gross loans and total non-performing loans), $D$ represents the total borrowed funds (which equals the sum of total deposits, money market funds, and other funds), $P^{a}$ is the average consumer price index, $P^{e}$ is the end-of-year consumer price index, and $t$ indicates year t. The consumer price index data are from the World Bank's World Development Indicators. All variables are expressed in local currency. The bank-level spread for the year 2000 is computed as the difference between the lending rate $i_{2000}^{L}$ and the deposit rate $i_{2000}^{D}$. This average interest rate spread, calculated using bank-level data and aggregating them at the countrylevel, will be defined as SPREAD2.

The relationship between the two indicators, SPREAD1 and SPREAD2, is shown in Figure 1, where the two variables are plotted one against the other together with a 45 
degree line. As expected, we see that the majority of the observations of SPREAD2 are higher (lie above the 45 degree line) than the SPREAD1 observations. An average higher value of SPREAD2 derives from eliminating non-performing loans and all the assets different from bank loans in the denominator of the average lending rate. Although the majority of SPREAD2 values is higher than those of SPREAD1, this is not always true. In fact, some composition effects are also at work, by which the spreads charged by smaller banks - included in SPREAD1 - are larger than those of the ten largest institutions that are the base of the SPREAD2 computation.

\subsection{The explanatory variables}

We use two broad measures to capture the efficiency and enforcement practices of property rights by the judiciary (and other legal institutions). The first variable is PROP which captures the degree of property protection in the country. This variable is gathered from the Index of Economic Freedom constructed by the Heritage Foundation. The index ranges from 1 to 5, with a higher score indicating more protection of private property (we reverse the scale of the original index). This variable captures (1) the freedom from government influence over the judicial system; (2) commercial code defining contracts; (3) sanctioning of foreign arbitration of contract disputes; (4) government expropriation of property; (5) corruption within the judiciary; (6) delays in receiving judicial decisions; and (7) legally granted and protected private property. We use this variable as a proxy for the degree to which property rights are enforced in general, and the value of collateral for bank loans in particular.

The second variable is LAW which captures the rule of law in the country. This variable is the assessment of the law and order tradition in the country from the 
International Country Risk Guide (ICRG) produced by the country-risk rating agency Political Risk Services Group. This variable has broader scope of coverage than the previous one in that it catches a broader notion of compliance with legal provisions. This index has previously been used by LLSV (1998), among others, as a proxy for the quality of the legal system and the enforcement on legal contracts.

We use the average of the monthly index for the year 2000. The scale of the index ranges from 0 to 6 , with higher scores for more tradition for law and order. As potential instruments for our judicial efficiency variables we use the legal origin variables ORIGIN first considered by LLSV (1998). We expand their list of countries and update the legal origins for a number of transition countries using the World Bank's Doing Business Database.

Several control variables will be considered to account for countries' macroeconomic and structural features and for the average level of bank efficiency. First, we control for the rate of inflation INFL using data from the IMF's International Financial Statistics (IFS) database. The rationale for introducing inflation among the determinants of bank lending spread needs to be related to the fact that, in equilibrium, net interest income should be such as to provide a constant real rate of return on banks' capital and therefore should be increasing in the level of inflation. Second, we control for a number of bank regulatory characteristics using the Barth, Caprio, and Levine (2001) database, such as whether the country imposes liquidity requirements, whether banks are allowed to engage in non-bank financial activities, and on the degree of entry into banking. All these features may affect the degree of competitiveness prevailing in the banking and financial markets or introduce quasi-fiscal elements that may affect the level 
of bank lending spreads. LIQREQ is a dummy variable that takes value of one if the authorities enforce liquidity requirements, and zero otherwise. RESTRICT is a variable that indicates the degree to which restrictions are imposed on banks to engage into nonbank financial activities, including real estate, insurance and securities. ENTRY is a variable that indicates the restrictions on entry into banking and is measured as the fraction of entry applications denied. From the same database, we draw the variable STATE which is the share of state ownership in the banking system of the country. To control for the impact of the structure of the banking system, we use the bank-5 concentration ratio from the same database. Our bank concentration variable CONC is defined as the ratio of deposits of the largest five banks in the country to the total deposits held by banks in the country. We also use a broader measure of restrictions on banking from the Heritage Foundation. This variable, which we will refer to as FBANK, measures the degree of freedom in banking, and captures the degree of (i) government ownership of banks; (ii) restrictions on the ability of foreign banks to open branches and subsidiaries; (iii) government influence over the allocation of bank credit; (iv) government regulations in banking; and (v) freedom of banks to offer different types of financial services, securities, and insurance policies.

We also control for the degree to which credit information is publicly available. Using data from the World Bank Credit Registries database, we construct a dummy variable PCR that takes value of one if the country has a public credit register, and zero otherwise. Finally, we will check whether the results are affected by the degree of dollarization in the country. The interest rate spreads we calculate do not distinguish between local currency and foreign currency. In countries where a large share of deposits 
and/or loans are denominated in (or linked to) a foreign currency, we are therefore likely to somewhat mismeasure the average interest rate spread. Ideally, one would want to calculate interest rates on loans and deposits in local currency. Unfortunately, such data is not widely available on a cross-country basis. We gather information on the degree of dollarization in each country from De Nicolo', Honohan, and Ize (2003). DOLL is the share of deposits in foreign currency. All variables are for the year 2000, except for the variables from the Barth et al. database that are for either the year 1999 or 2000 . Table 1 shows the country-averages of all the variables.

Finally, we control for the average level of bank operating efficiency through the ratio of operating expenses over total assets, orthogonalized with respect to PROP or LAW in order to capture the bank level of inefficiency that is not associated with the prevailing legal and regulatory framework.

After matching the available information for explanatory and dependent variables we ended up with a sample size of 106 countries for the estimation of the SPREAD1 regression. While some variables, such as SPREAD1 and PROP, are available for all sampled countries, others, such as SPREAD2, have a much smaller coverage as banks in many countries are not required to report interest income on loans separately from total interest income. As a result of lower data availability the number of countries for which we were able to obtain data for the explanatory and dependent variables for the SPREAD2 regression was limited to a total of 32 .

As a first assessment of whether spreads are indeed lower in countries with better judicial efficiency, we look at the correlations between our country variables. The correlation matrix is reported in Table 2. We find that SPREAD1 and SPREAD2 are 
highly correlated, despite the fact that they are constructed on the basis of a different set of data. We also find that several country characteristics are significantly correlated with the spreads. Consistent with our priors, spreads appear to be significantly higher on average in countries with more inflation and more restrictions on banking. Somewhat surprisingly, we find that spreads are higher in highly dollarized economies, suggesting that the dollarization variable captures more general weaknesses in the economy.

Most importantly, we find a strong correlation in the expected direction between our measures of judicial efficiency (PROP and LAW) and our two measures of spreads. In fact, together with the degree of inflation and dollarization of the economy, these correlations are the highest among all the variables considered.

\section{Empirical Results}

\subsection{An aggregate specification}

We use a multivariate approach to investigate the degree to which judicial efficiency affects the level of interest rate spreads across countries. Table 3 and 4 report the results of the OLS regressions of SPREAD1 on the two different indicators of judicial efficiency - PROP and LAW - together with the selected set of control variables. Table 5 and 6 report the same results for the regressions of SPREAD2.

We find that both measures of judicial efficiency are strongly correlated with our measures of interest rate spreads, even after controlling for a number of other country characteristics. Our baseline specification includes control for inflation, the level of liquidity reserves, market concentration and the presence of restrictions for banks to engage in non banks activities (column 3; Tables 3 to 6). Both the regressions of SPREAD1 and SPREAD2 show that our measures of protection of property rights remain 
strongly significant also after the inclusion of the relevant control variables. SPREAD2, which represents our most accurate spread measure, appears to be bear a relatively stronger relation to the indicators of property rights than SPREAD1. Among the control variables only the level of inflation and quasi fiscal restrictions associated to the level of required reserves appear to have an impact on banks' spreads.

Some further robustness tests are carried out (columns 4 to 8 in Tables 3 to 6) by adding to the baseline specification indicators of bank concentration, activity restrictions, entry restrictions, extent of state ownership, and presence of a public credit register. None of these additional controls appears to have a significant effect on banks' spreads nor on the explanatory power of the property rights proxies.

Finally, we test whether countries with a significant level of dollarization may have induced a downward bias in the average level of interest rates due to the presence of significant share of bank intermediation carried out in foreign currency and presumably with smaller spreads. As we can see in column 8 (Tables 3 to 6) the exclusion of countries with an extensive degree of dollarization - defined as a dollarization ratio in excess of 50 percent - does not alter our main conclusion as our proxies of property rights remain significant. The coefficients of the same variables, though, appear to be systematically smaller than in the larger sample, indicating that on average the use of foreign currencies does not bring with it smaller spreads and that, quite the contrary, dollarized economies are plagued by higher spreads between banks' borrowing and lending rates.

Apart from the effect associated to the exclusion of the dollarized economies, the coefficients of the proxies for property rights have shown a remarkable stability across 
different specification changes. If we refer to the baseline specification (column 3; Tables 3 to 6 ) we see that the property rights' coefficients oscillate between a minimum value of 1.41 and a maximum of 1.84 indicating that on average the improvement (increase) of one point in the scale of our indicators can bring about a reduction of banks' spread, measured in real terms, of between 141 to 184 basis points. Considering that the difference of the average value indicator of property rights (PROP) between G10 countries and non-G10 middle income countries - included in our sample - is equal to 1.4, we can estimate that the latter group of countries could achieve a reduction of the lending spread of about 2.0 to 2.5 percentage points as a result of the upgrading of its property rights institutions to the average level among G-10 countries. For low middle income countries, the reduction could be posited between 2.6 and 3.1 percentage points. While it is evident that these simulations should be considered as indicative, they nevertheless help to quantify the order of magnitude of the benefits that an economy could derive from improving its property right institutions. For example, a simple multiplication of these values for the volume of bank credit in the economy may give an indication of the fee that an inefficient judicial system is extracting from a middle income economy or (in positive terms) of the resources that would be reasonable to allocate to a judicial reform. This value would nevertheless provide just a lower bound estimate of the social cost of an inefficient judicial system as a poor protection of property rights, as discussed in Section 1, negatively affects the supply of bank credit itself.

We conduct another robustness test in order to control for the presence of potential endogeneity between judicial efficiency and interest rate spreads. It is in fact possible that in countries where a high level of spreads induces a low level of 
intermediation, governments face a low public pressure to improve the legal framework for lending. We use the legal origin of the country as instrument for our proxy for judicial efficiency. The first-stage results suggest that this is a valid instrument. The second-stage results are presented in Table 7. Panel A shows the results for SPREAD1 as dependent variable and panel B for SPREAD2 as dependent variable. Columns (2) and (4) exclude countries with a dollarization ratio of more than 50 percent. The IV results are broadly consistent with the OLS results in Table 3, although somewhat weaker in a few specifications, indicating that our results are generally robust to the use of instrumental variables.

These results are broadly consistent with those derived by Demirguc-Kunt, Laeven, and Levine (2003), notwithstanding the difference in the measures of the cost of financial intermediation. In both studies, institutional indicators such as the protection of private property rights, rather than bank regulations and bank structure, robustly explain cross-country variation in the cost of financial intermediation.

\subsection{A disaggregate specification}

Previous specifications did not allow to control for the potential effects of bank level indicators - such as size or operating efficiency - on the level of prevailing spreads. We have therefore replicated the previous sequence of estimation introducing two additional control variables: bank size and operating efficiency. The heavy concentration of banks that report interest income and expenses decomposition in a limited number of countries (France, Italy, and Japan) has not made possible to resort to a simple cross-section estimate based on individual banks data. In order to preserve a balance between the observations coming from different countries we have selected an alternative strategy. 
We have differentiated for each country the observations coming from larger and smaller banks, using as a definition of size the ratio of total assets over GDP and as a threshold values larger or smaller than 1 percent. This "relative" notion of size (relative to each country GDP), as opposed to an "absolute" one (given by the size of total assets) responds to the objective of testing whether banks that are larger in their own country would face lower judicial costs as a result of different level of political influence.

We have then considered the median bank from the segment of smaller and larger banks in each country as representative of the small and of the large banks and we have computed for each selected bank the value of the spread and the ratio of operating costs over total assets as an indicator of bank operating efficiency. The size of the sample and the measure of the spread for larger and smaller banks that have resulted from this procedure are reported in Table 8 .

This new set of regressions helps us to control more effectively for the effect of operating efficiency on the level of spreads. In this new specification the indicator of banks' efficiency is consistently significant at the 5 percent level across all specifications accounting for almost all the explanatory power accounted by inflation in the set of regressions of the previous section (Tables 9 and 10). This is perfectly consistent with the fact that lending spreads have to cover for higher operating expenses under an inflationary setting. We also observe that the "relative" size variable does not appear to have an autonomous relevance nor in isolation nor when interacted with the property rights proxies, indicating that there is no evidence that judicial inefficiency unevenly affects institutions of different size in the same country. 
Notwithstanding the different construction of the sample and the presence of bank level control variables the significance of the proxies of property rights does not appear to have been affected and the estimated coefficients appear to be only slightly smaller of those estimated in the previous section. Overall, a one point improvement (increase) of our indicators would imply a reduction of over 1.3 percentage points of the lending spread. Replicating the exercise of the previous section with the new estimated coefficients, we would get a reduction of the lending spreads of 1.9 percentage points for an average middle income country progressing toward the level of property rights protection available in an average G10 economy.

\section{Conclusions}

The definition of different measures of bank interest rate spreads for a large number of countries, both at the country level and at the level of individual banks, has allowed us to test the effect of judicial protection of property rights on the cost of bank credit. In particular, we have investigated the extent to which judicial efficiency affects bank lending spreads across countries after controlling for a number of other country characteristics. Judicial efficiency, in addition to inflation, has appeared to be "the" main driver of interest rate spreads. Not only the statistical significance of the effect of judicial efficiency on banks' spreads appears to be very strong but also the size of its impact appears to be remarkable indicating that for an average middle income country the improvement of its property rights protection to the average level prevailing in G10 countries would achieve a reduction of banks' lending spread of about 2.0 to 2.5 percentage points. 
This suggests that in addition to improving the overall macroeconomic climate in a country, reforms of the judiciary do improve the enforcement of legal contracts and are critical to lower the cost of financial intermediation.

More work is needed to investigate the specific channels through which improved legal efficiency lowers the cost of financial intermediation. Does it help reducing the volume of unproductive NPLs sitting in banks' balance sheets by eliminating the incentives to "strategic defaults" or by reducing the time required to repossess collateralized assets? How relevant are the benefits for different classes of borrowers? Although we have seen that there is no appreciable difference in the impact of judicial efficiency across banks of different sizes it may still be true that some differential effects could be associated with lending to different classes of borrowers. For example, it may be the case that judicial reforms have a different impact on the pricing of loans of different sizes or to borrowers with different access to foreign sources of finance. The extension of the present analysis to the impact of judicial reforms on the cost of credit for different layers of the population is left for future research. 


\section{References}

Barth, James R., Gerard Caprio, and Ross Levine, (2001), "The Regulation and Supervision of Banks Around the World: A New Database”. In: Robert E. Litan and Richard Herring (eds.), Integrating Emerging Market Countries into the Global Financial System, Brookings-Wharton Papers on Financial Services, Brookings Institutions Press, Washington, DC, 183-241.

Barth, James R., Gerard Caprio, and Ross Levine, (2003), "Bank Regulation and Supervision: What Works Best?”, Journal of Financial Intermediation, forthcoming.

Bianco, Magda, Tullio Jappelli, and Marco Pagano, (2001), “Courts and Banks: Effects of Judicial Enforcement on Credit Markets”, CSEF Working Paper n. 58.

Brock, P. L. and Liliana Rojas-Suarez, (2000), "Understanding the Behavior of Bank Spreads in Latin America”, Journal of Development Economics, 63, pp.113-134.

Castelar, Pinheiro Armando, and Celia Cabral, (2001), "Credit Markets in Brazil: The Role of Judicial Enforcement and Other Institutions", in Marco Pagano ed., Defusing Default: Incentives and Institutions, Washington, Johns Hopkins University Press.

Cristini, Moya, and Andrew Powell, (2001), "Credit Markets in Brazil: The Role of Judicial Enforcement and Other Institutions", in Marco Pagano ed., Defusing Default: Incentives and Institutions, Washington, Johns Hopkins University Press.

Claessens, Stijn, Asli Demirguc-Kunt, and Harry Huizinga, (2001), "How Does Foreign Entry Affect Domestic Banking Markets?", Journal of Banking and Finance 25, 891911.

Claessens, Stijn, and Luc Laeven, (2003), "What Drives Bank Competition? Some International Evidence”, Journal of Money, Credit, and Banking, forthcoming.

De Nicoló, Gianni, Patrick Honohan, and Alain Ize, (2003), "Dollarization of the Banking System: Good or Bad?”, Mimeo, World Bank.

Demirguc-Kunt, Asli, and Harry Huizinga, (1998), "Determinants of Commercial Bank Interest Margins and Profitability”, Policy Research Working Paper no. 1900, World Bank.

Demirguc-Kunt, Asli, and V. Maksimovic, (1998), “Law, Finance, and Firm Growth" Journal of Finance, 53, pp. 2107-2137.

Demirguc-Kunt, Asli, Luc Laeven, and Ross Levine, (2003), "Regulations, Market Structure, Institutions, and the Cost of Financial Intermediation", mimeo, World Bank.

Galindo, Arturo, (2001), “Creditor Rights and Credit Market: Where Do We Stand?”, IADB Working Paper n. 448.

Ho, Thomas and Anthony Saunders, (1981), "The Determinants of Bank Interest Margins: Theory and Empirical Evidence", Journal of Financial and Quantitative Analysis, 16, pp. 581-600. 
Honohan, Patrick, and Anquing Shi, (2003), "Deposit Dollarization and the Financial.Sector", in James Hanson, Patrick Honohan and Giovanni Majnoni (eds), Globalization and National Financial Systems, New York, Oxford University Press.

La Porta, Rafael, Florencio López-de-Silanes, Andrei Shleifer, and Robert Vishny, (1997), "Legal Determinants of External Finance," Journal of Finance,52, pp. 11311150

La Porta, Rafael, Florencio López-de-Silanes, Andrei Shleifer, and Robert Vishny (1998), "Law and Finance," Journal of Political Economy,100, pp. 113-1155.

Meador, Mark, (1982), “The Effects of Mortgage Laws on Home Mortgage Rates”, Journal of Economics and Business, 34, pp. 143-148.

Saunders, Anthony and Liliana Schumacher, (2000), "The Determinants of Bank Interest Rate Margins: an International Study", Journal of International Money and Finance, 19, pp. 813-132. 


\section{Figure 1: Comparison between SPREAD1 and SPREAD2}

This figure displays the relationship at the country-level between SPREAD1 and SPREAD2. Spreads are reported in percentages. The country codes are as follows: Argentina: ARG, Austria: AUT, Canada: CAN, China: CHN, Croatia: HRV, Denmark: DNK, Dominican Republic: DOM, Estonia: EST, France: FRA, Guyana: GUY, Haiti: HTI, Iceland: ISL, Israel: ISR, Italy: ITA, Japan: JPN, Jordan: JOR, Korea, Rep.: KOR, Kuwait: KWT, Latvia: LVA, Lithuania: LTU, Malaysia: MYS, Morocco: MAR, Oman: OMN, Poland: POL, Portugal: PRT, Slovenia: SVN, Sweden: SWE, Switzerland: CHE, Thailand: THA, United Kingdom: GBR, Vietnam: VNM.

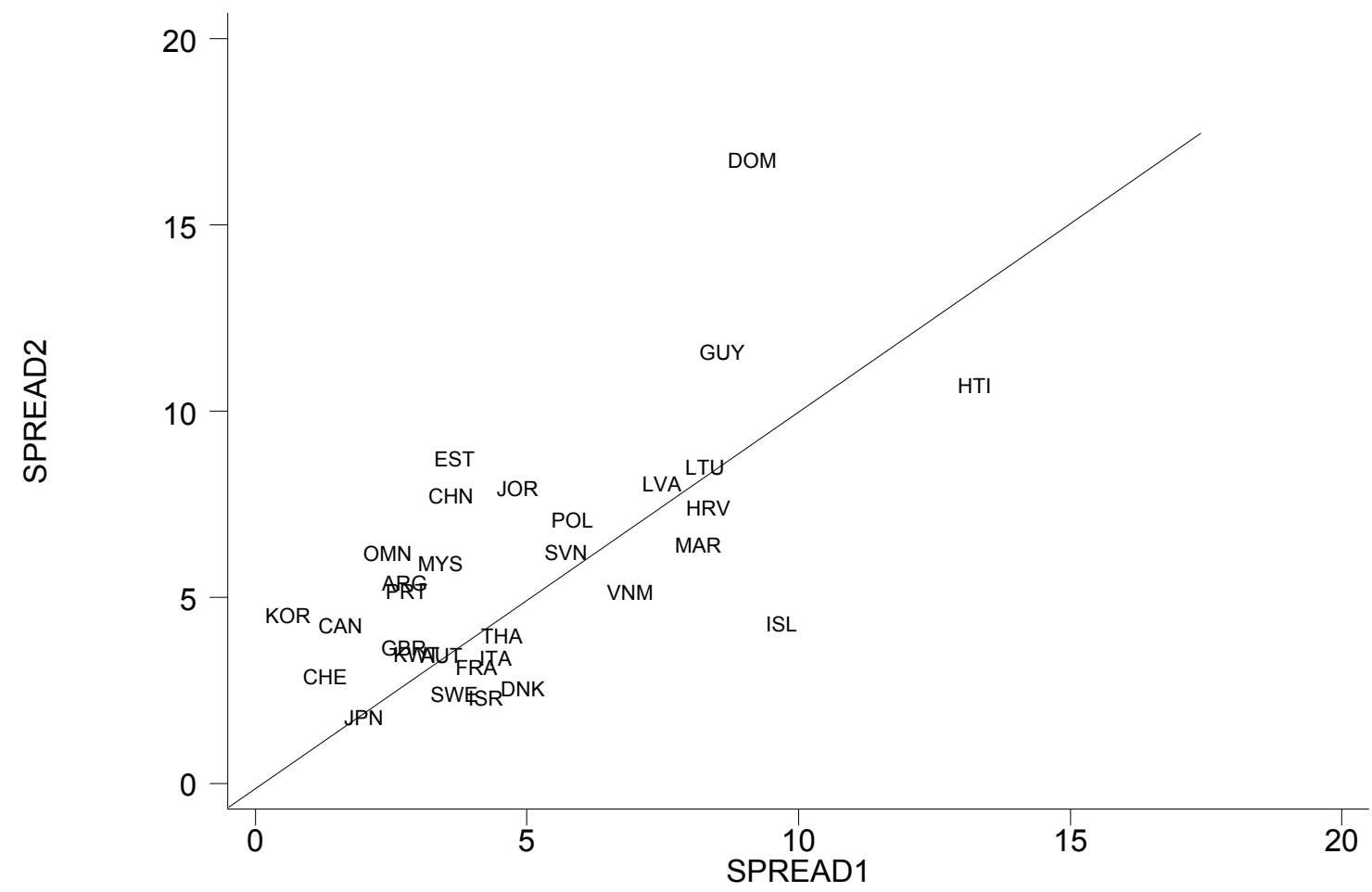


Table 1: $\quad$ Variables

All data for the year 2000. For Austria and Portugal, we use 1999 data for SPREAD1 and for the UK we use 1998 data for SPREAD1. INFL is the inflation rate. LIQREQ is a dummy variable taking value of one if the country imposes reserve requirements on banks, and zero otherwise. CONC is the 5-bank concentration ratio in terms of deposits. STATE is the share of state ownership in banking. ENTRY is the fraction of entry applications denied in banking, RESTRICT is an indicator of the degree of activity restrictions for banks. FBANK is a measure of overall banking freedom. LAW is a measure of the law and order in the country. PROP is a measure of the degree of property protection in the country. PCR is a dummy variable that takes value of one if the country has a public credit registry, and zero otherwise. DOLL is the fraction of dollarization in the country. ORIGIN is the legal origin of the country. Exact sources and definitions of each variable can be found in the main text.

\begin{tabular}{|c|c|c|c|c|c|c|c|c|c|c|c|c|c|c|}
\hline Country & Spread1 & Spread2 & Infl & Liqreq & Conc & State 1 & Entry & Restrict & Fbank & Law & Prop & Pcr & Doll & Origin \\
\hline Albania & 13.80 & & 0.05 & 1 & & & & & & $2 \quad 2.00$ & 2 & 0 & 27.80 & French \\
\hline Argentina & 2.75 & 5.18 & -0.94 & 1 & 48.00 & 30.00 & 0.00 & 7 & 4 & $4 \quad 5.00$ & 4 & 1 & 64.70 & French \\
\hline Armenia & 13.49 & & -0.81 & 1 & 50.10 & & & & & $4 \quad 3.00$ & 3 & 0 & 81.20 & French \\
\hline Australia & 4.67 & & 4.48 & 0 & 72.50 & 0.00 & 0.00 & 8 & 5 & $5 \quad 6.00$ & 5 & 0 & & English \\
\hline Austria & 3.43 & 3.22 & 2.35 & 1 & 38.00 & 4.10 & 0.07 & 5 & 4 & $4 \quad 6.00$ & 5 & 1 & 2.30 & German \\
\hline Azerbaijan & 6.76 & & 1.77 & 1 & 82.10 & & & & 2 & 24.00 & 2 & 0 & 78.00 & Socialist \\
\hline Bahamas & 1.92 & & 1.61 & & & & & & & $4 \quad 4.00$ & 5 & & 2.80 & \\
\hline Bahrain & 5.91 & & -0.70 & 1 & 70.53 & & 0.33 & 9 & 4 & $4 \quad 5.00$ & 5 & & & \\
\hline Bangladesh & 6.94 & & 3.92 & 1 & 64.80 & 69.86 & 0.79 & 12 & 2 & 22.08 & 2 & 1 & 0.50 & English \\
\hline Barbados & 5.22 & & 2.44 & & & & & & 4 & 4 & 4 & & 6.40 & \\
\hline Belgium & 4.40 & & 2.55 & 1 & 74.00 & & 0.00 & 9 & 4 & $4 \quad 5.00$ & 5 & 1 & & French \\
\hline Belize & 8.31 & & 0.61 & & & & & & 3 & 3 & 3 & & 1.90 & \\
\hline Bolivia & 23.61 & & 4.60 & 1 & 68.00 & 0.00 & 0.00 & 12 & & 3.00 & 3 & 1 & 92.40 & French \\
\hline Botswana & 5.24 & & 8.60 & & 100.00 & 2.39 & 0.33 & 10 & 4 & $4 \quad 4.00$ & 4 & 0 & & English \\
\hline Brazil & 39.63 & 14.57 & 7.04 & 1 & 57.60 & 51.50 & 0.74 & 10 & 3 & 32.00 & 3 & 1 & & French \\
\hline Bulgaria & 8.42 & & 10.32 & 1 & 63.00 & & & & 3 & 34.00 & 3 & 1 & 54.30 & German \\
\hline Cambodia & 10.51 & & -0.79 & 1 & 67.00 & 16.00 & 0.67 & 14 & 3 & 3 & 2 & & 93.20 & \\
\hline Cameroon & 17.00 & & -2.05 & & & & & & 2 & 2.25 & 2 & 1 & & French \\
\hline Canada & 1.58 & 4.04 & 2.75 & 0 & 75.70 & 0.00 & 0.13 & 7 & 4 & $4 \quad 6.00$ & 5 & 0 & & English \\
\hline Cape Verde & 7.60 & & -2.48 & & & & & & 1 & 1 & 4 & & & \\
\hline Chad & 17.00 & & 3.80 & & & & & & 2 & 2 & 2 & & & \\
\hline Chile & 5.64 & & 3.84 & 0 & 59.40 & 11.70 & & 11 & 3 & 35.00 & 5 & 1 & 9.00 & French \\
\hline China & 3.60 & 7.50 & 0.26 & & 75.00 & & 0.25 & 14 & 3 & 34.75 & 2 & 0 & 8.90 & Socialist \\
\hline Colombia & 6.64 & & 9.53 & & & & & & 4 & $4 \quad 1.17$ & 3 & 0 & & French \\
\hline Costa Rica & 11.51 & & 10.99 & & & & & & 3 & 34.00 & 3 & 1 & 41.10 & French \\
\hline Croatia & 8.33 & 7.19 & 5.27 & 1 & 57.32 & 36.99 & & 7 & 3 & 35.00 & 2 & 0 & 71.10 & German \\
\hline Cyprus & 1.50 & & 4.14 & 0 & 80.00 & 3.30 & 0.00 & 8 & 4 & $4 \quad 5.00$ & 4 & & & \\
\hline Czech Republic & 3.74 & & 3.90 & 1 & 74.00 & 19.00 & 0.36 & 8 & 5 & $5 \quad 5.00$ & 4 & 1 & 13.20 & German \\
\hline Denmark & 4.93 & 2.33 & 2.92 & 1 & 78.64 & 0.00 & 0.08 & 8 & 4 & $4 \quad 6.00$ & 5 & 0 & 4.40 & Scandin. \\
\hline Dominican Rep. & 9.15 & 16.53 & 7.72 & & & & & & 3 & 34.00 & 2 & 1 & & French \\
\hline Ecuador & 7.80 & & 96.09 & & & & & & 3 & 33.00 & 3 & 1 & 53.70 & French \\
\hline Egypt & 3.76 & & 2.68 & 1 & 64.70 & 66.60 & 1.00 & 13 & 2 & 24.00 & 3 & 1 & 23.30 & French \\
\hline El Salvador & 4.64 & & 2.27 & 1 & 75.00 & 7.00 & 0.21 & 13 & 4 & $4 \quad 3.00$ & 4 & & 8.90 & \\
\hline Estonia & 3.67 & 8.50 & 4.03 & 0 & 95.00 & 0.00 & 0.00 & 8 & 4 & $4 \quad 4.00$ & 4 & & 23.90 & \\
\hline Ethiopia & 4.21 & & 0.65 & & & & & & 2 & 25.00 & 2 & 0 & & English \\
\hline
\end{tabular}




\begin{tabular}{|c|c|c|c|c|c|c|c|c|c|c|c|c|c|c|}
\hline Country & Spread1 & Spread2 & Infl & Liqreq & Conc & State & Entry & Restrict & Fbank & Law & Prop & Pcr & Doll & Origin \\
\hline Finland & 3.98 & & 3.37 & 1 & 96.50 & 21.90 & 0.00 & 7 & & 36.00 & 5 & 0 & 2.10 & Scandin. \\
\hline France & 4.08 & 2.90 & 1.70 & 1 & 70.10 & & 0.00 & 6 & & 35.00 & 4 & 1 & & French \\
\hline Gabon & 17.00 & & 0.50 & & & & & & & $4 \quad 3.00$ & 3 & & & \\
\hline Gambia & 11.50 & & 0.84 & & 100.00 & 0.00 & 0.86 & 14 & & 25.00 & 3 & & & \\
\hline Georgia Rep. Of & 22.58 & & 4.06 & 1 & 57.30 & & & & & 2 & 2 & 0 & 77.90 & Socialist \\
\hline Germany & 6.23 & & 1.95 & 1 & 12.00 & 42.00 & 0.00 & 5 & & $3 \quad 5.67$ & 5 & 1 & & German \\
\hline Greece & 6.18 & & 3.15 & 0 & 70.00 & 13.00 & 0.00 & 9 & & 23.00 & 4 & 0 & 29.80 & French \\
\hline Guatemala & 10.71 & & 5.98 & 1 & 38.00 & 7.61 & 0.30 & 13 & & $4 \quad 2.00$ & 3 & 0 & 0.10 & French \\
\hline Guyana & 8.59 & 11.37 & 6.15 & 1 & 13.60 & 19.00 & 0.25 & 9 & & 34.00 & 3 & & & French \\
\hline Haití & 13.24 & 10.48 & 13.71 & & & & & & & 22.00 & 1 & & 39.10 & French \\
\hline Honduras & 10.89 & & 11.06 & 1 & 52.00 & 1.10 & 0.20 & 9 & & 32.00 & 3 & 1 & 28.70 & French \\
\hline Hong Kong & 4.70 & & -3.75 & & & & & & & $5 \quad 5.00$ & 5 & 0 & 47.10 & English \\
\hline Hungary & 2.97 & & 9.78 & 1 & & 2.50 & 0.33 & 9 & & $4 \quad 4.33$ & 4 & 0 & 21.80 & German \\
\hline Iceland & 9.69 & 4.07 & 5.16 & 1 & & 64.00 & 0.00 & 11 & & 36.00 & 5 & & & \\
\hline Indonesia & 5.95 & & 3.72 & 0 & 52.87 & 44.00 & 0.60 & 14 & & 22.00 & 3 & 1 & 20.80 & French \\
\hline Ireland & 4.67 & & 5.56 & 1 & & & 0.00 & 8 & & $4 \quad 6.00$ & 5 & 0 & & English \\
\hline Israel & 4.24 & 2.08 & 1.12 & 0 & 80.00 & & & 13 & & 35.00 & 4 & 0 & 18.70 & English \\
\hline Italy & 4.42 & 3.15 & 2.54 & 0 & 25.10 & 17.00 & 0.26 & 10 & & $4 \quad 6.00$ & 4 & 1 & 4.20 & French \\
\hline Jamaica & 11.73 & & 8.17 & 1 & 73.50 & 56.00 & & 12 & & 32.00 & 4 & 0 & 23.00 & English \\
\hline Japan & 2.00 & 1.56 & -0.67 & 1 & 31.05 & 1.15 & 0.00 & 13 & & 35.08 & 5 & 0 & 5.80 & German \\
\hline Jordan & 4.83 & 7.72 & 0.67 & 1 & 68.10 & 0.00 & & 11 & & $4 \quad 4.00$ & 4 & 1 & & French \\
\hline Kenya & 14.24 & & 9.98 & 1 & 62.00 & & 0.85 & 10 & & $4 \quad 2.00$ & 3 & 0 & 15.50 & English \\
\hline Korea Rep. Of & 0.61 & 4.31 & 2.25 & 1 & 47.50 & 29.70 & & 9 & & 34.00 & 5 & 0 & 3.40 & German \\
\hline Kuwait & 2.98 & 3.24 & 1.81 & 1 & & & & 10 & & 35.00 & 5 & & & \\
\hline Kyrgyzstan & 33.52 & & 18.69 & & 45.30 & & & & & 3 & 2 & 0 & 66.10 & Socialist \\
\hline Latvia & 7.49 & 7.85 & 2.65 & 1 & & & 0.00 & 8 & & $4 \quad 5.00$ & 3 & 0 & 45.20 & German \\
\hline Lebanon & 6.94 & & & 1 & 39.70 & 0.00 & 0.00 & 11 & & 44.00 & 3 & 0 & 62.30 & French \\
\hline Lesotho & 12.20 & & 6.13 & 1 & 56.00 & 51.00 & 0.00 & 12 & & 2 & 3 & & & \\
\hline Lithuania & 8.29 & 8.29 & 1.01 & 1 & 90.00 & 44.00 & 0.50 & 9 & & 34.00 & 3 & 1 & 45.70 & French \\
\hline Madagascar & 11.50 & & 12.03 & & & & & & & 23.00 & 3 & 1 & & French \\
\hline Malawi & 19.88 & & 29.58 & 1 & 73.30 & 48.90 & 0.29 & 13 & & 34.00 & 3 & 0 & 22.00 & English \\
\hline Malaysia & 3.41 & 5.70 & 1.53 & 1 & 30.00 & 0.00 & & 10 & & 33.00 & 4 & 1 & 3.30 & English \\
\hline Malta & 2.42 & & 2.37 & & 100.00 & 0.00 & 0.00 & & & 35.50 & 4 & & & \\
\hline Mexico & 11.96 & & 9.50 & & 80.00 & 25.00 & & 12 & & 22.00 & 3 & 1 & 10.40 & French \\
\hline Moldova Rep. Of & 8.91 & & 31.29 & & 70.63 & 7.05 & 0.33 & 7 & & 35.00 & 3 & 0 & 48.80 & Socialist \\
\hline Mongolia & 15.95 & & 11.60 & & & & & & & 34.00 & 3 & 1 & 43.70 & Socialist \\
\hline Morocco & 8.15 & 6.20 & 1.89 & 1 & 75.00 & 23.90 & 0.00 & 13 & & 36.00 & 3 & 1 & & French \\
\hline Mozambique & 9.34 & & 12.72 & & & & & & & 33.00 & 2 & 1 & 45.00 & French \\
\hline Namibia & 7.89 & & 8.99 & & 100.00 & & 0.67 & 11 & & $4 \quad 6.00$ & 4 & & & \\
\hline Netherlands & 1.90 & & 2.52 & 0 & 88.00 & 5.90 & 0.00 & 6 & & $5 \quad 6.00$ & 5 & 0 & 4.70 & French \\
\hline New Zealand & 3.86 & & 2.62 & 0 & 91.00 & 0.00 & 0.00 & 4 & & $5 \quad 6.00$ & 5 & 0 & 3.40 & English \\
\hline Nigeria & 9.58 & & 14.52 & 1 & 51.18 & 13.00 & 0.00 & & & 23.00 & 2 & 1 & 5.40 & English \\
\hline Norway & 1.49 & & 3.09 & & & & & & & 36.00 & 5 & 0 & 3.50 & Scandin. \\
\hline Oman & 2.44 & 5.97 & -1.11 & 1 & 76.70 & 0.00 & 0.00 & 13 & & 25.00 & 3 & & & \\
\hline Panama & 3.41 & & 1.50 & 1 & 30.40 & 11.56 & 0.06 & 8 & & $5 \quad 3.00$ & 3 & 0 & & French \\
\hline Paraguay & 11.06 & & 8.98 & & & & & & & $4 \quad 3.00$ & 2 & & 62.20 & \\
\hline
\end{tabular}




\begin{tabular}{|c|c|c|c|c|c|c|c|c|c|c|c|c|c|c|}
\hline Country & Spread1 & Spread2 & Infl & Liqreq & Conc & State 1 & Entry & Restrict & Fbank & Law & Prop & Pcr & Doll & Origin \\
\hline Peru & 14.62 & & 3.76 & 1 & 81.20 & 2.50 & 0.00 & 8 & 4 & 3.00 & 3 & 1 & 68.30 & French \\
\hline Philippines & 2.60 & & 4.32 & 1 & 45.59 & 12.12 & 0.34 & 7 & 3 & 3.08 & 4 & 0 & 32.30 & French \\
\hline Poland & 5.83 & 6.85 & 10.13 & 0 & 57.20 & 43.70 & 0.00 & 10 & 3 & 4.00 & 4 & 0 & 17.50 & German \\
\hline Portugal & 2.79 & 4.94 & 2.87 & 0 & 81.70 & 20.80 & 0.00 & 9 & 3 & 5.00 & 4 & 1 & & French \\
\hline Russian Federation & 17.93 & & 20.75 & 1 & 80.00 & 68.00 & & 8 & 2 & 3.00 & 3 & 0 & 37.40 & Socialist \\
\hline Singapore & 4.12 & & 1.36 & 1 & & 0.00 & & 8 & 4 & 6.00 & 5 & 0 & & English \\
\hline Slovakia & 6.44 & & 12.04 & 1 & 71.30 & & & & 3 & 4.58 & 3 & 1 & 17.60 & German \\
\hline Slovenia & 5.72 & 5.99 & 8.87 & 1 & 63.80 & 39.60 & 0.00 & 9 & 3 & 5.00 & 4 & 1 & 34.50 & German \\
\hline South Africa & 5.30 & & 5.25 & 1 & 85.00 & 0.00 & 0.26 & 8 & 3 & 2.00 & 3 & 0 & 4.20 & English \\
\hline Spain & 2.22 & & 3.43 & 0 & 49.00 & 0.00 & 0.00 & 7 & 4 & 4.00 & 4 & 1 & 1.80 & French \\
\hline Sri Lanka & 6.99 & & 6.18 & 1 & & 55.00 & & 7 & 3 & 3.00 & 3 & 0 & & English \\
\hline Sweden & 3.67 & 2.19 & 1.00 & 0 & & 0.00 & 0.07 & 9 & 4 & 6.00 & 4 & 0 & 2.10 & Scandin. \\
\hline Switzerland & 1.29 & 2.67 & 1.58 & 1 & 65.00 & 15.00 & 0.00 & 5 & 5 & 6.00 & 5 & 0 & 0.60 & German \\
\hline Tanzania & 14.19 & & 5.92 & & & & & & 3 & 5.00 & 3 & 0 & 30.20 & English \\
\hline Thailand & 4.54 & 3.74 & 1.55 & 1 & 74.83 & 30.67 & 1.00 & 9 & 3 & 5.00 & 4 & 0 & 1.40 & English \\
\hline Trinidad \& Tobago & 8.35 & & 3.56 & 0 & 75.30 & 15.00 & 0.25 & 9 & 4 & 4.00 & 5 & & 27.80 & \\
\hline Uganda & 13.08 & & 2.83 & & & & & & 3 & 4.00 & 3 & 0 & 29.90 & English \\
\hline Ukraine & 27.81 & & & & & & & & 2 & 4.00 & 2 & 1 & 38.40 & Socialist \\
\hline United Kingdom & 2.73 & 3.44 & 2.93 & 0 & & 0.00 & & 5 & 5 & 6.00 & 5 & 0 & 15.10 & English \\
\hline Uruguay & 36.94 & & 4.76 & & & & & & 4 & 3.00 & 4 & 1 & 81.60 & French \\
\hline United States & 2.77 & & 3.38 & 0 & 20.80 & 0.00 & 0.00 & 12 & 4 & 6.00 & 5 & 0 & & English \\
\hline Venezuela & 8.90 & & 16.20 & 1 & 63.82 & 4.87 & 0.11 & 10 & 3 & 4.00 & 3 & 1 & 0.20 & French \\
\hline Vietnam & 6.90 & 4.94 & -1.71 & 1 & 65.00 & & & 14 & 2 & 5.00 & 1 & 1 & 41.20 & Socialist \\
\hline Zambia & 18.56 & & & 1 & 83.00 & 23.00 & 0.00 & 13 & 4 & 4.00 & 3 & 0 & 53.20 & English \\
\hline Zimbabwe & 18.04 & & 55.87 & & & & & & 3 & 2.50 & 2 & 0 & & English \\
\hline Total & 8.67 & 5.90 & 6.42 & 0.77 & 65.27 & 18.72 & 0.20 & 9.58 & 3.26 & 4.18 & 3.50 & 0.44 & 29.28 & \\
\hline
\end{tabular}




\section{Table 2: $\quad$ Correlation matrix}

All data for the year 2000. For Austria and Portugal, we use 1999 data for SPREAD1 and for the UK we use 1998 data for SPREAD1. INFL is the inflation rate. LIQREQ is a dummy variable taking value of one if the country imposes reserve requirements on banks, and zero otherwise. CONC is the 5-bank concentration ratio in terms of deposits. STATE is the share of state ownership in banking. ENTRY is the fraction of entry applications denied in banking, RESTRICT is an indicator of the degree of activity restrictions for banks. FBANK is a measure of overall banking freedom. LAW is a measure of the law and order in the country. PROP is a measure of the degree of property protection in the country. PCR is a dummy variable that takes value of one if the country has a public credit registry, and zero otherwise. DOLL is the fraction of dollarization in the country. ORIGIN is the legal origin of the country. Exact sources and definitions of each variable can be found in the main text.

\begin{tabular}{|c|c|c|c|c|c|c|c|c|c|c|c|c|c|}
\hline & Spread1 & Spread2 I & & Liqreq & Conc & State & Entry & Restrict $\mathrm{I}$ & Fbank & Law & Prop & Pcr & Doll \\
\hline Spread1 & 1.00 & & & & & & & & & & & & \\
\hline \multirow[t]{2}{*}{ Spread2 } & $* * * 0.59$ & 1.00 & & & & & & & & & & & \\
\hline & 0.00 & & & & & & & & & & & & \\
\hline \multirow[t]{2}{*}{ Infl } & $* * * 0.61$ & $* * * 0.53$ & 1.00 & & & & & & & & & & \\
\hline & 0.00 & 0.01 & & & & & & & & & & & \\
\hline \multirow[t]{2}{*}{ Liqreq } & $* * 0.33$ & 0.01 & 0.22 & 1.00 & & & & & & & & & \\
\hline & 0.02 & 0.98 & 0.12 & & & & & & & & & & \\
\hline \multirow[t]{2}{*}{ Conc } & 0.12 & 0.39 & 0.10 & -0.09 & 1.00 & & & & & & & & \\
\hline & 0.43 & 0.11 & 0.49 & 0.56 & & & & & & & & & \\
\hline \multirow[t]{2}{*}{ State } & $* * * 0.48$ & 0.37 & 0.20 & $* * 0.33$ & 0.08 & 1.00 & & & & & & & \\
\hline & 0.00 & 0.14 & 0.19 & 0.03 & 0.61 & & & & & & & & \\
\hline \multirow[t]{2}{*}{ Entry } & 0.25 & 0.06 & 0.07 & ${ }^{*} 0.26$ & 0.05 & $* * * 0.50$ & 1.00 & & & & & & \\
\hline & 0.11 & 0.82 & 0.66 & 0.10 & 0.78 & 0.00 & & & & & & & \\
\hline \multirow[t]{2}{*}{ Restrict } & $* * 0.30$ & 0.12 & 0.03 & 0.09 & -0.12 & $* * * 0.37$ & $* * * 0.41$ & 1.00 & & & & & \\
\hline & 0.03 & 0.60 & 0.83 & 0.55 & 0.43 & 0.01 & 0.01 & & & & & & \\
\hline \multirow[t]{2}{*}{ Fbank } & $* * *-0.46$ & $*_{-} 0.37$ & $* *-0.27$ & $* *_{-} 0.30$ & $0.07^{*}$ & $* * *-0.58$ & $* *-0.33 *$ & $* * *-0.52$ & 1.00 & & & & \\
\hline & 0.00 & 0.09 & 0.03 & 0.03 & 0.64 & 0.00 & 0.03 & 0.00 & & & & & \\
\hline \multirow[t]{2}{*}{ Law } & $* * *-0.45$ & $* * *-0.73$ & $* *-0.28$ & $*_{-}-0.28$ & 0.01 & $*_{-0.26}$ & $* * *-0.47 *$ & $* * *-0.44$ & $* * * 0.53$ & 1.00 & & & \\
\hline & 0.00 & 0.00 & 0.03 & 0.05 & 0.92 & 0.09 & 0.00 & 0.00 & 0.00 & & & & \\
\hline \multirow[t]{2}{*}{ Prop } & $* * *-0.60$ & $* * *-0.66 *$ & $* * *-0.36$ & $* *_{-} 0.33$ & -0.09 & $* *_{-} 0.34$ & $* * *-0.50 *$ & $* * *-0.52$ & $* * * 0.64$ & $* * * 0.62$ & 1.00 & & \\
\hline & 0.00 & 0.00 & 0.00 & 0.02 & 0.55 & 0.02 & 0.00 & 0.00 & 0.00 & 0.00 & & & \\
\hline \multirow[t]{2}{*}{ Pcr } & 0.11 & 0.21 & 0.02 & 0.13 & -0.22 & 0.21 & 0.10 & 0.11 & $* * *-0.33$ & -0.18 & $* *-0.31$ & 1.00 & \\
\hline & 0.40 & 0.38 & 0.85 & 0.39 & 0.14 & 0.19 & 0.55 & 0.45 & 0.01 & 0.18 & 0.02 & & \\
\hline \multirow[t]{2}{*}{ Doll } & $* * * 0.49$ & $* * * 0.69$ & $* * 0.31$ & 0.09 & 0.22 & $* * 0.33$ & 0.08 & 0.06 & $* *-0.27$ & $-0.18 *$ & $* * *-0.43$ & 0.09 & 1.00 \\
\hline & 0.00 & 0.00 & 0.02 & 0.59 & 0.17 & 0.05 & 0.64 & 0.71 & 0.04 & 0.19 & 0.00 & 0.51 & \\
\hline
\end{tabular}


Table 3: Spreads and Judicial Efficiency: OLS Results.

Dependent variable is SPREAD1. Column 8 excludes countries where dollarization exceeds 50 percent. All data for the year 2000. For Austria and Portugal, we use 1999 data for SPREAD1 and for the UK we use 1998 data for SPREAD1. INFL is the inflation rate. LIQREQ is a dummy variable taking value of one if the country imposes reserve requirements on banks, and zero otherwise. CONC is the 5-bank concentration ratio in terms of deposits. STATE is the share of state ownership in banking. ENTRY is the fraction of entry applications denied in banking, RESTRICT is an indicator of the degree of activity restrictions for banks. FBANK is a measure of overall banking freedom. LAW is a measure of the law and order in the country. PROP is a measure of the degree of property protection in the country. PCR is a dummy variable that takes value of one if the country has a public credit registry, and zero otherwise. DOLL is the fraction of dollarization in the country. ORIGIN is the legal origin of the country. Exact sources and definitions of each variable can be found in the main text. Robust standard errors in parentheses. ${ }^{*}$ significant at $10 \%$; $* *$ significant at $5 \%$; *** significant at $1 \%$.

\begin{tabular}{|c|c|c|c|c|c|c|c|c|}
\hline & $\begin{array}{l}\text { (1) } \\
\text { Snread1 }\end{array}$ & $\begin{array}{l}\text { (2) } \\
\text { Snread1 }\end{array}$ & $\begin{array}{l}\text { (3) } \\
\text { Snread1 }\end{array}$ & $\begin{array}{l}\text { (4) } \\
\text { Snread1 }\end{array}$ & $\begin{array}{l}\text { (5) } \\
\text { Snread1 }\end{array}$ & $\begin{array}{l}\text { (6) } \\
\text { Snread1 }\end{array}$ & (7) & $\begin{array}{l}\text { (8) } \\
\text { Snead1 }\end{array}$ \\
\hline Prop & $-3.242 * * *$ & $-2.242^{* * *}$ & $-1.772 * *$ & $-1.951^{* *}$ & $-1.653 * * *$ & $-1.976^{* *}$ & $-1.678^{* *}$ & $-0.922 * *$ \\
\hline & $(0.539)$ & $(0.608)$ & $(0.667)$ & $(0.754)$ & $(0.608)$ & $(0.888)$ & $(0.679)$ & $(0.379)$ \\
\hline Infl & & $0.391 * * *$ & $0.486^{* * *}$ & $0.430^{* * *}$ & $0.536^{* * *}$ & $0.427 * * *$ & $0.493 * * *$ & $0.519^{* * *}$ \\
\hline & & $(0.084)$ & $(0.085)$ & $(0.089)$ & $(0.116)$ & $(0.098)$ & $(0.080)$ & $(0.059)$ \\
\hline Liqreq & & $\begin{array}{l}1.720^{* *} \\
(0.821)\end{array}$ & $\begin{array}{l}1.956^{* *} \\
(0.822)\end{array}$ & $\begin{array}{l}1.601^{*} \\
(0.926)\end{array}$ & $\begin{array}{l}1.742^{*} \\
(0.917)\end{array}$ & $\begin{array}{l}1.863^{* *} \\
(0.923)\end{array}$ & $\begin{array}{l}1.729 * * \\
(0.787)\end{array}$ & $\begin{array}{l}0.773 \\
(0.622)\end{array}$ \\
\hline Conc & & $\begin{array}{l}-0.004 \\
(0.018)\end{array}$ & $\begin{array}{l}0.007 \\
(0.018)\end{array}$ & $\begin{array}{l}0.012 \\
(0.016)\end{array}$ & $\begin{array}{l}0.014 \\
(0.021)\end{array}$ & $\begin{array}{l}-0.005 \\
(0.025)\end{array}$ & $\begin{array}{l}0.005 \\
(0.018)\end{array}$ & $\begin{array}{l}0.008 \\
(0.018)\end{array}$ \\
\hline Restrict & & & $\begin{array}{l}0.217 \\
(0.173)\end{array}$ & $\begin{array}{l}0.215 \\
(0.205)\end{array}$ & $\begin{array}{l}0.181 \\
(0.199)\end{array}$ & $\begin{array}{l}0.087 \\
(0.320)\end{array}$ & $\begin{array}{l}0.150 \\
(0.150)\end{array}$ & $\begin{array}{l}0.156 \\
(0.145)\end{array}$ \\
\hline State & & & & $\begin{array}{l}0.028 \\
(0.055)\end{array}$ & & & & \\
\hline Pcr & & & & & $\begin{array}{l}1.895 \\
(1.572)\end{array}$ & & & \\
\hline Entry & & & & & & $\begin{array}{l}2.594 \\
(4.952)\end{array}$ & & \\
\hline Fbank & & & & & & & $\begin{array}{l}0.000 \\
(0.515)\end{array}$ & \\
\hline Observations & 106 & 66 & 59 & 52 & 48 & 50 & 58 & 42 \\
\hline R-squared & 0.23 & 0.33 & 0.37 & 0.37 & 0.39 & 0.35 & 0.39 & 0.75 \\
\hline
\end{tabular}


Table 4: Spreads and Judicial Efficiency: OLS Results

Dependent variable is SPREAD1. Column 8 excludes countries where dollarization exceeds 50 percent. All data for the year 2000. For Austria and Portugal, we use 1999 data for SPREAD1 and for the UK we use 1998 data for SPREAD1. INFL is the inflation rate. LIQREQ is a dummy variable taking value of one if the country imposes reserve requirements on banks, and zero otherwise. CONC is the 5-bank concentration ratio in terms of deposits. STATE is the share of state ownership in banking. ENTRY is the fraction of entry applications denied in banking, RESTRICT is an indicator of the degree of activity restrictions for banks. FBANK is a measure of overall banking freedom. LAW is a measure of the law and order in the country. PROP is a measure of the degree of property protection in the country. PCR is a dummy variable that takes value of one if the country has a public credit registry, and zero otherwise. DOLL is the fraction of dollarization in the country. ORIGIN is the legal origin of the country. Exact sources and definitions of each variable can be found in the main text. Robust standard errors in parentheses. ${ }^{*}$ significant at $10 \%$; $* *$ significant at $5 \%$; *** significant at $1 \%$.

\begin{tabular}{|c|c|c|c|c|c|c|c|c|}
\hline & $\begin{array}{l}\text { (1) } \\
\text { Spread1 }\end{array}$ & $\begin{array}{l}\text { (2) } \\
\text { Spread1 }\end{array}$ & $\begin{array}{l}\text { (3) } \\
\text { Spread1 }\end{array}$ & $\begin{array}{l}\text { (4) } \\
\text { Spread1 }\end{array}$ & $\begin{array}{l}\text { (5) } \\
\text { Snread1 }\end{array}$ & $\begin{array}{l}\text { (6) } \\
\text { Snread1 }\end{array}$ & $\begin{array}{l}\text { (7) } \\
\text { Snread1 }\end{array}$ & $\begin{array}{l}\text { (8) } \\
\text { Snread1 }\end{array}$ \\
\hline Law & $\begin{array}{l}-2.460^{* * *} \\
(0.503)\end{array}$ & $\begin{array}{l}-1.725^{* *} \\
(0.718)\end{array}$ & $\begin{array}{l}-1.414^{*} \\
(0.794)\end{array}$ & $\begin{array}{l}-1.359 \\
(0.836)\end{array}$ & $\begin{array}{l}-1.487^{*} \\
(0.834)\end{array}$ & $\begin{array}{l}-1.459^{*} \\
(0.798)\end{array}$ & $\begin{array}{l}-1.242 \\
(0.814)\end{array}$ & $\begin{array}{l}-0.551^{*} \\
(0.272)\end{array}$ \\
\hline Infl & & $\begin{array}{l}0.370 * * * \\
(0.079)\end{array}$ & $\begin{array}{l}0.444 * * * \\
(0.065)\end{array}$ & $\begin{array}{l}0.418^{* * *} \\
(0.089)\end{array}$ & $\begin{array}{l}0.489 * * * \\
(0.088)\end{array}$ & $\begin{array}{l}0.407 * * * \\
(0.084)\end{array}$ & $\begin{array}{l}0.460 * * * \\
(0.061)\end{array}$ & $\begin{array}{l}0.514 * * * \\
(0.063)\end{array}$ \\
\hline Liqreq & & $\begin{array}{l}2.158 * * * \\
(0.784)\end{array}$ & $\begin{array}{l}2.275^{* * *} * \\
(0.812)\end{array}$ & $\begin{array}{l}2.013^{*} \\
(1.017)\end{array}$ & $\begin{array}{l}1.642 \\
(1.004)\end{array}$ & $\begin{array}{l}2.236 * * \\
(1.077)\end{array}$ & $\begin{array}{l}1.999 * * \\
(0.770)\end{array}$ & $\begin{array}{l}0.940 \\
(0.664)\end{array}$ \\
\hline Conc & & $\begin{array}{l}0.017 \\
(0.020)\end{array}$ & $\begin{array}{l}0.019 \\
(0.021)\end{array}$ & $\begin{array}{l}0.021 \\
(0.021)\end{array}$ & $\begin{array}{l}0.030 \\
(0.024)\end{array}$ & $\begin{array}{l}0.006 \\
(0.025)\end{array}$ & $\begin{array}{l}0.016 \\
(0.019)\end{array}$ & $\begin{array}{l}0.014 \\
(0.020)\end{array}$ \\
\hline Restrict & & & $\begin{array}{l}0.256 \\
(0.199)\end{array}$ & $\begin{array}{l}0.200 \\
(0.266)\end{array}$ & $\begin{array}{l}0.183 \\
(0.226)\end{array}$ & $\begin{array}{l}0.155 \\
(0.357)\end{array}$ & $\begin{array}{l}0.156 \\
(0.186)\end{array}$ & $\begin{array}{l}0.210 \\
(0.160)\end{array}$ \\
\hline State & & & & $\begin{array}{l}0.033 \\
(0.053)\end{array}$ & & & & \\
\hline Pcr & & & & & $\begin{array}{l}2.529 \\
(1.598)\end{array}$ & & & \\
\hline Entry & & & & & & $\begin{array}{l}2.408 \\
(4.543)\end{array}$ & & \\
\hline Fbank & & & & & & & $\begin{array}{l}-0.199 \\
(0.495)\end{array}$ & \\
\hline Observations & 98 & 63 & 57 & 50 & 48 & 48 & 56 & 42 \\
\hline R-squared & 0.23 & 0.37 & 0.39 & 0.38 & 0.43 & 0.37 & 0.40 & 0.75 \\
\hline
\end{tabular}


Table 5: Spreads and Judicial Efficiency: OLS Results.

Dependent variable is SPREAD2. Column 8 excludes countries where dollarization exceeds 50 percent. All data for the year 2000 . For Austria and Portugal, we use 1999 data for SPREAD1 and for the UK we use 1998 data for SPREAD1. INFL is the inflation rate. LIQREQ is a dummy variable taking value of one if the country imposes reserve requirements on banks, and zero otherwise. CONC is the 5-bank concentration ratio in terms of deposits. STATE is the share of state ownership in banking. ENTRY is the fraction of entry applications denied in banking, RESTRICT is an indicator of the degree of activity restrictions for banks. FBANK is a measure of overall banking freedom. LAW is a measure of the law and order in the country. PROP is a measure of the degree of property protection in the country. PCR is a dummy variable that takes value of one if the country has a public credit registry, and zero otherwise. DOLL is the fraction of dollarization in the country. ORIGIN is the legal origin of the country. Exact sources and definitions of each variable can be found in the main text. Robust standard errors in parentheses. $*$ significant at $10 \%$; $* *$ significant at $5 \%$; *** significant at $1 \%$.

\begin{tabular}{|c|c|c|c|c|c|c|c|c|}
\hline & $\begin{array}{l}\text { (1) } \\
\text { Spread2 }\end{array}$ & $\begin{array}{l}\text { (2) } \\
\text { Spread2 }\end{array}$ & $\begin{array}{l}\text { (3) } \\
\text { Spread2 }\end{array}$ & $\begin{array}{l}\text { (4) } \\
\text { Spread2 }\end{array}$ & $\begin{array}{l}\text { (5) } \\
\text { Spread2 }\end{array}$ & $\begin{array}{l}\text { (6) } \\
\text { Spread2 }\end{array}$ & $\begin{array}{l}\text { (7) } \\
\text { Spread2 }\end{array}$ & $\begin{array}{l}\text { (8) } \\
\text { Spread2 }\end{array}$ \\
\hline Prop & $\begin{array}{l}-1.907 * * * \\
(0.552)\end{array}$ & $\begin{array}{l}-1.442 * * \\
(0.531)\end{array}$ & $\begin{array}{l}-1.430 * * \\
(0.627)\end{array}$ & $\begin{array}{l}-2.136 * * \\
(0.947)\end{array}$ & $\begin{array}{l}-0.848 * \\
(0.483)\end{array}$ & $\begin{array}{l}-3.188^{* * *} \\
(0.702)\end{array}$ & $\begin{array}{l}-1.725^{* *} \\
(0.687)\end{array}$ & $\begin{array}{l}-1.241 * * \\
(0.501)\end{array}$ \\
\hline Infl & & $\begin{array}{l}0.538 * * \\
(0.225)\end{array}$ & $\begin{array}{l}0.540 * * \\
(0.248)\end{array}$ & $\begin{array}{l}0.402 * \\
(0.215)\end{array}$ & $\begin{array}{l}0.536^{*} \\
(0.293)\end{array}$ & $\begin{array}{l}0.399^{*} \\
(0.183)\end{array}$ & $\begin{array}{l}0.581 * * \\
(0.252)\end{array}$ & $\begin{array}{l}0.338 * * * \\
(0.076)\end{array}$ \\
\hline Liqreq & & $\begin{array}{l}1.121 \\
(1.119)\end{array}$ & $\begin{array}{l}1.134 \\
(1.235)\end{array}$ & $\begin{array}{l}0.654 \\
(1.238)\end{array}$ & $\begin{array}{l}1.510 \\
(1.176)\end{array}$ & $\begin{array}{l}-0.101 \\
(1.383)\end{array}$ & $\begin{array}{l}1.448 \\
(1.345)\end{array}$ & $\begin{array}{l}-0.162 \\
(0.840)\end{array}$ \\
\hline Conc & & $\begin{array}{l}0.002 \\
(0.022)\end{array}$ & $\begin{array}{l}0.003 \\
(0.023)\end{array}$ & $\begin{array}{l}0.005 \\
(0.023)\end{array}$ & $\begin{array}{l}0.014 \\
(0.020)\end{array}$ & $\begin{array}{l}-0.005 \\
(0.023)\end{array}$ & $\begin{array}{l}0.004 \\
(0.025)\end{array}$ & $\begin{array}{l}0.016 \\
(0.024)\end{array}$ \\
\hline Restrict & & & $\begin{array}{l}0.010 \\
(0.200)\end{array}$ & $\begin{array}{l}0.030 \\
(0.247)\end{array}$ & $\begin{array}{l}0.096 \\
(0.178)\end{array}$ & $\begin{array}{l}-0.207 \\
(0.217)\end{array}$ & $\begin{array}{l}0.178 \\
(0.246)\end{array}$ & $\begin{array}{l}-0.158 \\
(0.184)\end{array}$ \\
\hline State & & & & $\begin{array}{l}-0.007 \\
(0.040)\end{array}$ & & & & \\
\hline Pcr & & & & & $\begin{array}{l}1.684 * \\
(0.941)\end{array}$ & & & \\
\hline Entry & & & & & & $\begin{array}{l}1.483 \\
(2.687)\end{array}$ & & \\
\hline Fbank & & & & & & & $\begin{array}{l}1.165 \\
(1.001)\end{array}$ & \\
\hline Observations & 32 & 24 & 24 & 21 & 21 & 18 & 24 & 17 \\
\hline R-squared & 0.40 & 0.51 & 0.51 & 0.58 & 0.57 & 0.74 & 0.54 & 0.52 \\
\hline
\end{tabular}


Table 6 Spreads and Judicial Efficiency: OLS Results

Dependent variable is SPREAD2. Column 8 excludes countries where dollarization exceeds 50 percent. All data for the year 2000. For Austria and Portugal, we use 1999 data for SPREAD1 and for the UK we use 1998 data for SPREAD1. INFL is the inflation rate. LIQREQ is a dummy variable taking value of one if the country imposes reserve requirements on banks, and zero otherwise. CONC is the 5-bank concentration ratio in terms of deposits. STATE is the share of state ownership in banking. ENTRY is the fraction of entry applications denied in banking, RESTRICT is an indicator of the degree of activity restrictions for banks. FBANK is a measure of overall banking freedom. LAW is a measure of the law and order in the country. PROP is a measure of the degree of property protection in the country. PCR is a dummy variable that takes value of one if the country has a public credit registry, and zero otherwise. DOLL is the fraction of dollarization in the country. ORIGIN is the legal origin of the country. Exact sources and definitions of each variable can be found in the main text. Robust standard errors in parentheses. ${ }^{*}$ significant at $10 \%$; $* *$ significant at $5 \%$; $* * *$ significant at $1 \%$.

\begin{tabular}{|c|c|c|c|c|c|c|c|c|}
\hline & $\begin{array}{l}\text { (1) } \\
\text { Snroadn }\end{array}$ & $\begin{array}{l}\text { (2) } \\
\text { Snreadr }\end{array}$ & $\begin{array}{l}\text { (3) } \\
\text { Snread? }\end{array}$ & $\begin{array}{l}\text { (4) } \\
\text { Snread? }\end{array}$ & $\begin{array}{l}\text { (5) } \\
\text { Snead2 }\end{array}$ & $\begin{array}{l}\text { (6) } \\
\text { Snread? }\end{array}$ & $\begin{array}{l}\text { (7) } \\
\text { Snread? }\end{array}$ & $\begin{array}{l}\text { (8) } \\
\text { Snreadn }\end{array}$ \\
\hline & Spread2 & Spread2 & Spread2 & Spread2 & Spread2 & Spread2 & & \\
\hline Law & $\begin{array}{l}-2.282 * * * \\
(0.411)\end{array}$ & $\begin{array}{l}-1.891 * * * \\
(0.455)\end{array}$ & $\begin{array}{l}-1.840 * * * \\
(0.519)\end{array}$ & $\begin{array}{l}-1.840 * * * \\
(0.533)\end{array}$ & $\begin{array}{l}-1.561 * * \\
(0.527)\end{array}$ & $\begin{array}{l}-2.405^{* * *} \\
(0.561)\end{array}$ & $\begin{array}{l}-1.882 * * * \\
(0.508)\end{array}$ & $\begin{array}{l}-1.525 * * * \\
(0.379)\end{array}$ \\
\hline Infl & & $\begin{array}{l}0.339 * * \\
(0.155)\end{array}$ & $\begin{array}{l}0.360^{*} \\
(0.182)\end{array}$ & $\begin{array}{l}0.281 \\
(0.210)\end{array}$ & $\begin{array}{l}0.350^{*} \\
(0.181)\end{array}$ & $\begin{array}{l}0.191 \\
(0.191)\end{array}$ & $\begin{array}{l}0.376^{*} \\
(0.189)\end{array}$ & $\begin{array}{l}0.175^{*} \\
(0.093)\end{array}$ \\
\hline Liqreq & & $\begin{array}{l}1.053 \\
(0.887)\end{array}$ & $\begin{array}{l}1.117 \\
(0.958)\end{array}$ & $\begin{array}{l}0.596 \\
(0.947)\end{array}$ & $\begin{array}{l}0.858 \\
(0.971)\end{array}$ & $\begin{array}{l}0.369 \\
(0.857)\end{array}$ & $\begin{array}{l}1.288 \\
(0.998)\end{array}$ & $\begin{array}{l}-0.353 \\
(0.805)\end{array}$ \\
\hline Conc & & $\begin{array}{l}0.015 \\
(0.024)\end{array}$ & $\begin{array}{l}0.015 \\
(0.025)\end{array}$ & $\begin{array}{l}0.019 \\
(0.025)\end{array}$ & $\begin{array}{l}0.032^{*} \\
(0.016)\end{array}$ & $\begin{array}{l}0.001 \\
(0.027)\end{array}$ & $\begin{array}{l}0.017 \\
(0.026)\end{array}$ & $\begin{array}{l}0.029 \\
(0.019)\end{array}$ \\
\hline Restrict & & & $\begin{array}{l}0.063 \\
(0.176)\end{array}$ & $\begin{array}{l}0.048 \\
(0.205)\end{array}$ & $\begin{array}{l}0.035 \\
(0.162)\end{array}$ & $\begin{array}{l}0.087 \\
(0.269)\end{array}$ & $\begin{array}{l}0.143 \\
(0.239)\end{array}$ & $\begin{array}{l}-0.099 \\
(0.196)\end{array}$ \\
\hline State & & & & $\begin{array}{l}0.012 \\
(0.030)\end{array}$ & & & & \\
\hline Pcr & & & & & $\begin{array}{l}1.689 * * \\
(0.720)\end{array}$ & & & \\
\hline Entry & & & & & & $\begin{array}{l}0.191 \\
(1.969)\end{array}$ & & \\
\hline Fbank & & & & & & & $\begin{array}{l}0.438 \\
(0.672)\end{array}$ & \\
\hline Observations & 32 & 24 & 24 & 21 & 21 & 18 & 24 & 17 \\
\hline R-squared & 0.50 & 0.64 & 0.64 & 0.67 & 0.75 & 0.76 & 0.65 & 0.66 \\
\hline
\end{tabular}


Table $7 \quad$ Spreads and Judicial Efficiency: Instrumental Variables Results

Dependent variable is either SPREAD1 in Panel A and SPREAD2 in Panel B. As instrument for property rights, we use the country's legal origin. We only report the second-stage regression results. Columns 2 and 4 exclude countries where dollarization exceeds 50 percent. Robust standard errors in parentheses. * significant at $10 \%$; ** significant at $5 \%$; ** significant at $1 \%$.

\section{Panel A: SPREAD1}

\begin{tabular}{lllll}
\hline \multirow{2}{*}{ Depend. Var. } & $(1)$ & $(2)$ & $(3)$ & $(4)$ \\
Prop & Spread1 & Spread1 & Spread1 & Spread1 \\
& $-2.945^{* *}$ & $-1.815^{* * *}$ & & \\
Law & $(1.333)$ & $(0.656)$ & & \\
& & & $-2.393^{*}$ & -0.681 \\
Infl & & & $(1.285)$ & $(0.604)$ \\
& $0.467^{* * *}$ & $0.495^{* * *}$ & $0.378^{* * *}$ & $0.499^{* * *}$ \\
Liqreq & $(0.102)$ & $(0.057)$ & $(0.096)$ & $(0.074)$ \\
& 1.191 & 0.561 & 1.422 & 1.102 \\
Conc & $(1.048)$ & $(0.740)$ & $(1.138)$ & $(0.740)$ \\
& 0.003 & 0.000 & 0.026 & 0.017 \\
Restrict & $(0.025)$ & $(0.019)$ & $(0.032)$ & $(0.022)$ \\
& 0.018 & -0.015 & 0.097 & 0.210 \\
& $(0.233)$ & $(0.195)$ & $(0.294)$ & $(0.194)$ \\
Observations & 48 & & & \\
R-squared & 0.37 & 39 & 48 & 39 \\
\hline
\end{tabular}

Panel B: SPREAD2

\begin{tabular}{lllll}
\hline \multirow{2}{*}{ Depend. Var. } & $(1)$ & $(2)$ & $(3)$ & $(4)$ \\
Prop & Spread2 & Spread2 & Spread2 & Spread2 \\
& -1.598 & $-1.103^{* *}$ & & \\
Law & $(0.957)$ & $(0.442)$ & & -1.426 \\
& & & $-2.915^{* * *}$ & $(0.851)$ \\
Infl & & & $(0.953)$ & 0.187 \\
& $0.488^{*}$ & $0.343^{* * *}$ & 0.141 & $(0.121)$ \\
Liqreq & $(0.255)$ & $(0.077)$ & $(0.194)$ & -0.068 \\
& 1.386 & 0.416 & 0.179 & $(1.025)$ \\
Conc & $(1.052)$ & $(0.718)$ & $(1.418)$ & 0.023 \\
& 0.001 & 0.005 & 0.036 & $(0.022)$ \\
Restrict & $(0.021)$ & $(0.025)$ & $(0.032)$ & -0.068 \\
& -0.014 & -0.090 & -0.127 & $(0.242)$ \\
Observations & $(0.160)$ & $(0.156)$ & $(0.240)$ & 16 \\
R-squared & 21 & & & 0.59 \\
\hline
\end{tabular}




\section{Table 8: Variables}

Banks are divided into two groups by size and then the median spread is calculated for each group. Banks are considered large if their assets scaled by GDP is larger than 1 percent and small otherwise. For ten countries there are data only for large banks.

\begin{tabular}{lrrrr}
\hline & \multicolumn{2}{c}{ Large banks } & \multicolumn{2}{c}{ Small banks } \\
Country & Median spread & Number of banks & Median spread & Number of banks \\
\hline Argentina & 5.00 & 8 & 8.03 & 19 \\
Austria & 2.31 & 2 & n.a. & n.a. \\
Canada & 3.42 & 4 & 2.35 & 16 \\
China & 5.76 & 5 & 4.33 & 2 \\
Croatia & 6.49 & 9 & 11.33 & 6 \\
Denmark & 2.46 & 7 & 6.48 & 12 \\
Dominican Republic & 15.04 & 10 & 18.61 & 3 \\
Estonia & 6.62 & 2 & 12.24 & 1 \\
France & 2.25 & 14 & 2.55 & 85 \\
Iceland & 4.56 & 5 & n.a. & n.a. \\
Israel & 1.57 & 11 & 1.86 & 2 \\
Italy & 2.83 & 23 & 4.77 & 215 \\
Japan & 1.38 & 25 & 2.65 & 617 \\
Korea, Rep. & 1.31 & n.a. & n.a. \\
Latvia & 7.58 & 8 & n.a. & n.a. \\
Lithuania & 8.88 & 3 & 7.41 & 1 \\
Malaysia & 5.85 & 2.58 & 6 \\
Morocco & 5.92 & n.a. & n.a. \\
Oman & 5.97 & n.a. & n.a. \\
Poland & 7.27 & 3.88 & 5 \\
Portugal & 5.57 & 11 & 9.05 & 4 \\
Slovenia & 5.03 & n.a. & n.a. \\
Sweden & 1.62 & 2.26 & 4 \\
Switzerland & 2.67 & n.a. & n.a. \\
Thailand & 3.89 & 14 & n.a. & n.a. \\
United Kingdom & 3.44 & n.a. & n.a. \\
Mean & 4.91 & 6.12 & 62.38 \\
Number of observations & 26 & & 998 \\
\hline
\end{tabular}


Table 9: Spreads by Size and Judicial Efficiency: OLS Results.

Dependent variable is SPREAD2. Column 10 excludes countries where dollarization exceeds 50 percent. OVERHEADS_R is the residual of the regression of overhead costs over total assets on property rights. SMALL is a dummy that takes the value of 1 when referring to the group of smaller banks in each country. SMALL*PROP is the interaction between the size dummy and the judicial variables. INFL is the inflation rate. LIQREQ is a dummy variable taking value of one if the country imposes reserve requirements on banks, and zero otherwise. CONC is the 5-bank concentration ratio in terms of deposits. STATE is the share of state ownership in banking. ENTRY is the fraction of entry applications denied in banking, RESTRICT is an indicator of the degree of activity restrictions for banks. FBANK is a measure of overall banking freedom. LAW is a measure of the law and order in the country. PROP is a measure of the degree of property protection in the country. PCR is a dummy variable that takes value of one if the country has a public credit registry, and zero otherwise. DOLL is the fraction of dollarization in the country. ORIGIN is the legal origin of the country. Robust standard errors in parentheses. * significant at $10 \% ; * *$ significant at $5 \% ; * * * \% ; * * *$ significant at $1 \%$.

\begin{tabular}{|c|c|c|c|c|c|c|c|c|c|c|}
\hline & $\begin{array}{c}(1) \\
\text { Spread2 }\end{array}$ & $\begin{array}{c}(2) \\
\text { Spread2 }\end{array}$ & $\begin{array}{c}(3) \\
\text { Spread2 }\end{array}$ & $\begin{array}{c}(4) \\
\text { Spread2 }\end{array}$ & $\begin{array}{c}(5) \\
\text { Spread2 }\end{array}$ & $\begin{array}{c}(6) \\
\text { Spread2 }\end{array}$ & $\begin{array}{c}(7) \\
\text { Spread2 }\end{array}$ & $\begin{array}{c}(8) \\
\text { Spread2 }\end{array}$ & $\begin{array}{c}(9) \\
\text { Spread2 }\end{array}$ & $\begin{array}{c}(10) \\
\text { Spread2 }\end{array}$ \\
\hline Prop & $\begin{array}{l}-2.263 * * * \\
{[0.635]}\end{array}$ & $\begin{array}{l}-2.036^{* * *} \\
{[0.644]}\end{array}$ & $\begin{array}{l}-2.062 * * * \\
{[0.498]}\end{array}$ & $\begin{array}{l}-1.371 * * * \\
{[0.414]}\end{array}$ & $\begin{array}{l}-1.375 * * * \\
{[0.489]}\end{array}$ & $\begin{array}{l}-1.385^{* *} \\
{[0.494]}\end{array}$ & $\begin{array}{l}-1.159 * * \\
{[0.455]}\end{array}$ & $\begin{array}{l}-1.403 * * * \\
{[0.406]}\end{array}$ & $\begin{array}{l}-1.221 * * \\
{[0.529]}\end{array}$ & $\begin{array}{l}-1.712 * * \\
{[0.771]}\end{array}$ \\
\hline Small & $\begin{array}{l}0.97 \\
{[1.047]}\end{array}$ & $\begin{array}{l}3.22 \\
{[6.104]}\end{array}$ & $\begin{array}{l}2.292 \\
{[4.793]}\end{array}$ & $\begin{array}{l}0.517 \\
{[3.080]}\end{array}$ & $\begin{array}{l}0.504 \\
{[3.257]}\end{array}$ & $\begin{array}{l}2.516 \\
{[2.980]}\end{array}$ & $\begin{array}{l}1.371 \\
{[3.484]}\end{array}$ & $\begin{array}{l}-2.252 \\
{[4.085]}\end{array}$ & $\begin{array}{l}0.23 \\
{[3.315]}\end{array}$ & $\begin{array}{l}-4.718 \\
{[4.578]}\end{array}$ \\
\hline Small*Prop & & $\begin{array}{l}-0.59 \\
{[1.448]}\end{array}$ & $\begin{array}{l}-0.653 \\
{[1.138]}\end{array}$ & $\begin{array}{l}-0.098 \\
{[0.679]}\end{array}$ & $\begin{array}{l}-0.095 \\
{[0.730]}\end{array}$ & $\begin{array}{l}-0.508 \\
{[0.680]}\end{array}$ & $\begin{array}{l}-0.294 \\
{[0.789]}\end{array}$ & $\begin{array}{l}0.578 \\
{[0.912]}\end{array}$ & $\begin{array}{l}-0.054 \\
{[0.752]}\end{array}$ & $\begin{array}{l}1.106 \\
{[0.948]}\end{array}$ \\
\hline Overheads_r & & & $\begin{array}{l}1.019 * * * \\
{[0.238]}\end{array}$ & $\begin{array}{l}0.886^{* * * *} \\
{[0.257]}\end{array}$ & $\begin{array}{l}0.885 * * * \\
{[0.288]}\end{array}$ & $\begin{array}{l}0.803 * * * \\
{[0.257]}\end{array}$ & $\begin{array}{l}0.717 * * \\
{[0.281]}\end{array}$ & $\begin{array}{l}0.957 * * * \\
{[0.250]}\end{array}$ & $\begin{array}{l}0.966 * * * \\
{[0.277]}\end{array}$ & $\begin{array}{l}1.166 * * \\
{[0.469]}\end{array}$ \\
\hline Infl & & & & $\begin{array}{l}0.276^{*} \\
{[0.149]}\end{array}$ & $\begin{array}{l}0.275^{*} \\
{[0.153]}\end{array}$ & $\begin{array}{l}0.187 \\
{[0.160]}\end{array}$ & $\begin{array}{l}0.302 \\
{[0.187]}\end{array}$ & $\begin{array}{l}0.155 \\
{[0.125]}\end{array}$ & $\begin{array}{l}0.268 \\
{[0.159]}\end{array}$ & $\begin{array}{l}0.297^{*} \\
{[0.165]}\end{array}$ \\
\hline Liqreq & & & & $\begin{array}{l}0.328 \\
{[0.861]}\end{array}$ & $\begin{array}{l}0.323 \\
{[0.812]}\end{array}$ & $\begin{array}{l}-0.181 \\
{[0.764]}\end{array}$ & $\begin{array}{l}0.508 \\
{[0.895]}\end{array}$ & $\begin{array}{l}-0.77 \\
{[0.723]}\end{array}$ & $\begin{array}{l}0.136 \\
{[0.933]}\end{array}$ & $\begin{array}{l}0.151 \\
{[0.881]}\end{array}$ \\
\hline Conc & & & & $\begin{array}{l}0.01 \\
{[0.015]}\end{array}$ & $\begin{array}{l}0.01 \\
{[0.016]}\end{array}$ & $\begin{array}{l}0.025 \\
{[0.017]}\end{array}$ & $\begin{array}{l}0.007 \\
{[0.019]}\end{array}$ & $\begin{array}{l}0.033 * \\
{[0.016]}\end{array}$ & $\begin{array}{l}0.006 \\
{[0.016]}\end{array}$ & $\begin{array}{l}-0.008 \\
{[0.025]}\end{array}$ \\
\hline Restrict & & & & & $\begin{array}{l}-0.003 \\
{[0.172]}\end{array}$ & $\begin{array}{l}0.11 \\
{[0.122]}\end{array}$ & $\begin{array}{l}-0.009 \\
{[0.154]}\end{array}$ & $\begin{array}{l}0.206 \\
{[0.154]}\end{array}$ & $\begin{array}{l}-0.076 \\
{[0.243]}\end{array}$ & $\begin{array}{l}-0.143 \\
{[0.200]}\end{array}$ \\
\hline State & & & & & & $\begin{array}{l}-0.014 \\
{[0.029]}\end{array}$ & & & & \\
\hline Pcr & & & & & & & $\begin{array}{l}0.638 \\
{[0.854]}\end{array}$ & & & \\
\hline Entry & & & & & & & & $\begin{array}{l}-0.722 \\
{[0.787]}\end{array}$ & & \\
\hline Fbank & & & & & & & & & $\begin{array}{l}-0.542 \\
{[0.865]}\end{array}$ & \\
\hline Observations & 42 & 42 & 42 & 33 & 33 & 29 & 30 & 26 & 33 & 27 \\
\hline R-squared & 0.39 & 0.40 & 0.58 & 0.63 & 0.63 & 0.76 & 0.60 & 0.80 & 0.64 & 0.59 \\
\hline
\end{tabular}




\section{Table 10: $\quad$ Spreads by Size and Judicial Efficiency: OLS Results}

Dependent variable is SPREAD2. Column 10 excludes countries where dollarization exceeds 50 percent. OVERHEADS_R is the residual of the regression of overhead costs over total assets on property rights. SMALL is a dummy that takes the value of 1 when referring to the group of smaller banks in each country. SMALL*LAW is the interaction between the size dummy and the law and order variable. INFL is the inflation rate. LIQREQ is a dummy variable taking value of one if the country imposes reserve requirements on banks, and zero otherwise. CONC is the 5-bank concentration ratio in terms of deposits. STATE is the share of state ownership in banking. ENTRY is the fraction of entry applications denied in banking, RESTRICT is an indicator of the degree of activity restrictions for banks. FBANK is a measure of overall banking freedom. LAW is a measure of the law and order in the country. PROP is a measure of the degree of property protection in the country. PCR is a dummy variable that takes value of one if the country has a public credit registry, and zero otherwise. DOLL is the fraction of dollarization in the country. ORIGIN is the legal origin of the country. Robust standard errors in parentheses. * significant at $10 \% ; * *$ significant at $5 \% ; * * * \% ; * * *$ significant at $1 \%$.

\begin{tabular}{|c|c|c|c|c|c|c|c|c|c|c|}
\hline & $\begin{array}{l}(1) \\
\text { Spread2 }\end{array}$ & $\begin{array}{l}(2) \\
\text { Spread2 }\end{array}$ & $\begin{array}{l}(3) \\
\text { Spread2 }\end{array}$ & $\begin{array}{l}(4) \\
\text { Spread2 }\end{array}$ & $\begin{array}{l}(5) \\
\text { Spread2 }\end{array}$ & $\begin{array}{l}(6) \\
\text { Spread2 }\end{array}$ & $\begin{array}{l}(7) \\
\text { Spread2 }\end{array}$ & $\begin{array}{l}(8) \\
\text { Spread2 }\end{array}$ & $\begin{array}{l}(9) \\
\text { Spread2 }\end{array}$ & $\begin{array}{l}(10) \\
\text { Spread2 }\end{array}$ \\
\hline Law & $\begin{array}{l}-1.805^{* *} \\
{[0.732]}\end{array}$ & $\begin{array}{l}-1.946 * * * \\
{[0.693]}\end{array}$ & $\begin{array}{l}-1.911 * * * \\
{[0.463]}\end{array}$ & $\begin{array}{l}-1.343 * * * \\
{[0.350]}\end{array}$ & $\begin{array}{l}-1.325 * * * \\
{[0.400]}\end{array}$ & $\begin{array}{l}-1.299 * * * \\
{[0.440]}\end{array}$ & $\begin{array}{l}-1.354 * * * \\
{[0.372]}\end{array}$ & $\begin{array}{l}-0.678 \\
{[0.578]}\end{array}$ & $\begin{array}{l}-1.127 * * \\
{[0.490]}\end{array}$ & $\begin{array}{l}-1.868 * * * \\
{[0.372]}\end{array}$ \\
\hline Small & $\begin{array}{l}0.99 \\
{[1.174]}\end{array}$ & $\begin{array}{l}-0.775 \\
{[9.028]}\end{array}$ & $\begin{array}{l}-0.55 \\
{[6.147]}\end{array}$ & $\begin{array}{l}-4.645^{*} \\
{[2.367]}\end{array}$ & $\begin{array}{l}-4.639^{*} \\
{[2.410]}\end{array}$ & $\begin{array}{l}-4.561 \\
{[2.912]}\end{array}$ & $\begin{array}{l}-7.204 * * * \\
{[1.810]}\end{array}$ & $\begin{array}{l}-1.867 \\
{[4.317]}\end{array}$ & $\begin{array}{l}-4.314 \\
{[2.636]}\end{array}$ & $\begin{array}{l}-5.894 * * \\
{[2.352]}\end{array}$ \\
\hline Small*Law & & $\begin{array}{l}0.357 \\
{[1.670]}\end{array}$ & $\begin{array}{l}0.024 \\
{[1.141]}\end{array}$ & $\begin{array}{l}0.934^{*} \\
{[0.475]}\end{array}$ & $\begin{array}{l}0.933 * \\
{[0.483]}\end{array}$ & $\begin{array}{l}0.996^{*} \\
{[0.575]}\end{array}$ & $\begin{array}{l}1.456 * * * \\
{[0.375]}\end{array}$ & $\begin{array}{l}0.376 \\
{[0.807]}\end{array}$ & $\begin{array}{l}0.85 \\
{[0.523]}\end{array}$ & $\begin{array}{l}1.201 * * \\
{[0.475]}\end{array}$ \\
\hline Overheads_r & & & $\begin{array}{l}1.208 * * * \\
{[0.281]}\end{array}$ & $\begin{array}{l}1.023 * * * \\
{[0.224]}\end{array}$ & $\begin{array}{l}1.032 * * * \\
{[0.240]}\end{array}$ & $\begin{array}{l}0.948 * * * \\
{[0.293]}\end{array}$ & $\begin{array}{l}0.910 * * * \\
{[0.269]}\end{array}$ & $\begin{array}{l}1.023 * * * \\
{[0.210]}\end{array}$ & $\begin{array}{l}1.093 * * * \\
{[0.225]}\end{array}$ & $\begin{array}{l}1.098 * * * \\
{[0.342]}\end{array}$ \\
\hline Infl & & & & $\begin{array}{l}0.322 * * \\
{[0.145]}\end{array}$ & $\begin{array}{l}0.330 * * \\
{[0.150]}\end{array}$ & $\begin{array}{l}0.204 \\
{[0.172]}\end{array}$ & $\begin{array}{l}0.393^{*} \\
{[0.194]}\end{array}$ & $\begin{array}{l}0.166 \\
{[0.119]}\end{array}$ & $\begin{array}{l}0.304 * \\
{[0.158]}\end{array}$ & $\begin{array}{l}0.230 * \\
{[0.113]}\end{array}$ \\
\hline Liqreq & & & & $\begin{array}{l}0.627 \\
{[0.852]}\end{array}$ & $\begin{array}{l}0.669 \\
{[0.880]}\end{array}$ & $\begin{array}{l}0.101 \\
{[0.819]}\end{array}$ & $\begin{array}{l}0.712 \\
{[1.009]}\end{array}$ & $\begin{array}{l}-0.67 \\
{[0.734]}\end{array}$ & $\begin{array}{l}0.298 \\
{[0.972]}\end{array}$ & $\begin{array}{l}-0.354 \\
{[0.827]}\end{array}$ \\
\hline Conc & & & & $\begin{array}{l}0.013 \\
{[0.015]}\end{array}$ & $\begin{array}{l}0.013 \\
{[0.015]}\end{array}$ & $\begin{array}{l}0.028 * \\
{[0.015]}\end{array}$ & $\begin{array}{l}0.012 \\
{[0.017]}\end{array}$ & $\begin{array}{l}0.039 * * \\
{[0.016]}\end{array}$ & $\begin{array}{l}0.007 \\
{[0.014]}\end{array}$ & $\begin{array}{l}-0.006 \\
{[0.019]}\end{array}$ \\
\hline Restrict & & & & & $\begin{array}{l}0.028 \\
{[0.187]}\end{array}$ & $\begin{array}{l}0.134 \\
{[0.151]}\end{array}$ & $\begin{array}{l}0.008 \\
{[0.188]}\end{array}$ & $\begin{array}{l}0.303 * * \\
{[0.143]}\end{array}$ & $\begin{array}{l}-0.087 \\
{[0.264]}\end{array}$ & $\begin{array}{l}-0.261 \\
{[0.196]}\end{array}$ \\
\hline State & & & & & & $\begin{array}{l}0.006 \\
{[0.025]}\end{array}$ & & & & \\
\hline Pcr & & & & & & & $\begin{array}{l}0.992 \\
{[0.944]}\end{array}$ & & & \\
\hline Entry & & & & & & & & $\begin{array}{l}-0.576 \\
{[0.766]}\end{array}$ & & \\
\hline Fbank & & & & & & & & & $\begin{array}{l}-0.782 \\
{[0.954]}\end{array}$ & \\
\hline Observations & 42 & 42 & 42 & 33 & 33 & 29 & 30 & 26 & 33 & 27 \\
\hline R-squared & 0.21 & 0.21 & 0.49 & 0.63 & 0.63 & 0.75 & 0.63 & 0.79 & 0.64 & 0.68 \\
\hline
\end{tabular}


